\title{
Distribution and dynamics of intertidal macrobenthos predicted from remote sensing: response to microphytobenthos and environment
}

\author{
D. van der Wal ${ }^{1, *}$, P. M. J. Herman ${ }^{1}$, R. M. Forster ${ }^{1,4}{ }^{4}$ T. Ysebaert ${ }^{1}$, F. Rossi ${ }^{1}$, \\ E. Knaeps' ${ }^{2}$, Y. M. G. Plancke ${ }^{3}$, S. J. Ides ${ }^{3}$ \\ ${ }^{1}$ Netherlands Institute of Ecology (NIOO-KNAW), Centre for Estuarine and Marine Ecology, PO Box 140, 4400 AC, Yerseke, \\ Netherlands \\ ${ }^{2}$ Flemish Institute for Technological Research (VITO), Centre for Remote Sensing and Earth Observation Processes, \\ Boeretang 200, 2400, Mol, Belgium \\ ${ }^{3}$ Flanders Hydraulics Research, Flemish government, Berchemlei 115, 2140, Antwerp, Belgium \\ ${ }^{4}$ Present address: Centre for Environment, Fisheries \& Aquaculture Science (CEFAS) Pakefield Road, Lowestoft NR33 0HT, UK
}

\begin{abstract}
We investigated which variables, including environmental variables and food availability, could predict the spatial distribution and dynamics of benthic macrofauna on an intertidal flat. A time series of macrobenthos and sediment grain size samples was complemented by time series of microphytobenthos and saltmarsh vegetation biomass and sediment grain size from airborne hyperspectral remote sensing, and elevation from laser altimetry. Response models were constructed to predict biomass and species richness of macrobenthos as a function of the environmental variables. Total biomass and species richness was best predicted by a combination of microphytobenthos biomass and sediment characteristics as explanatory variables. Deep deposit feeders and surface deposit feeders also responded best to a combination of variables, with deep deposit feeders responding more strongly to sediment grain size and surface deposit feeders responding more strongly to microphytobenthos biomass. The environmental conditions to reach maximum biomass differed for each macrobenthos species. Application of the response models to the remote sensingderived maps of the environmental variables enabled significant predictions of the spatial distribution of macrobenthos biomass, demonstrating the differences in distribution of the macrobenthos species. The models also revealed the sensitivity of the macrobenthic community to environmental change. In situ and remote sensing data demonstrated a significant fining of the sediment and a (temporal) increase in average microphytobenthos biomass. Field observations also showed a significant increase in species richness and changes in the relative abundance of species, with a decrease in Bathyporeia pilosa, and an increase in Nereis diversicolor, Pygospio elegans and Heteromastus filiformis. Such changes in macrobenthos biomass and species richness were indeed predicted from the response models. The study demonstrates that the synoptic remote sensing techniques combined with field sampling allow efficient ecological mapping and monitoring.
\end{abstract}

KEY WORDS: Hyperspectral remote sensing $\cdot$ Intertidal zone $\cdot$ Ecosystem response modelling Ecosystem monitoring $\cdot$ Benthic communities $\cdot$ Mapping

Resale or republication not permitted without written consent of the publisher

\section{INTRODUCTION}

The intertidal zones of soft sediment estuaries and shallow lagoons in temperate regions are ranked among the most productive marine systems (Heip et al. 1995). These zones accommodate most of the macro- benthic species and provide valuable feeding areas for large crustaceans, (wading) birds and fish (Herman et al. 1999). On an intertidal flat, the benthic macrofauna community is mainly structured by environmental variables (Zajac \& Whitlatch 1982, Menge \& Olson 1990). Sediment composition may regulate 
larval recruitment and species composition (e.g. Sanders 1958, Gray 1974, Holland et al. 1987, Warwick et al. 1991). A number of relevant species directly depend on sediment grain size, whereas for other species, the link depends on factors covarying with grain size, such as the hydrodynamic regime (Snelgrove \& Butman 1994). Depth (or emersion time) and salinity could also be controlling factors for macrobenthos distribution (Ysebaert et al. 2002).

In addition, the availability of food may be an important structuring factor for macrobenthos communities (Levinton \& Bianchi 1981, Lopez \& Levinton 1987, Graf 1992, Heip et al. 1995, Miller et al. 1996, Cahoon 1999, Herman et al. 1999). Intertidal macrobenthos mainly feed on microphytobenthos or phytoplankton (Taghon et al. 1980, Herman et al. 2000, Riisgård \& Kamermans 2001) or other sources, such as detritus from saltmarsh macrophytes (Créach et al. 1997). Averaged macrobenthos biomass in well-mixed shallow waters was found to increase linearly with estimated primary productivity (Herman et al. 1999). Such relationships have, however, seldom been studied at an intertidal flat.

In recent years, response models of large-scale macrobenthos distribution patterns have been developed to interpret changes in the benthic community, and to predict future species response to anticipated environmental change. The models predict species occurrence, abundance or biomass as a function of habitat characteristics, such as sediment grain size and depth (e.g. Ysebaert et al. 2002, Thrush et al. 2003, 2005, Ellis et al. 2006). Food resources have rarely been included in response models as a factor explaining macrobenthos structure. This is mainly because there is a shortage of consistent data on food resources required for the models, as traditional sampling is costly or inadequate.

Remote sensing is ideally suited to provide time series on the distribution of key variables (Kerr \& Ostrovsky 2003) that can be used in such models. In the intertidal zone, remote sensing techniques have been applied to obtain synoptic information on elevation (e.g. Cracknell 1999, Saye et al. 2005), grain size of emerged sediments (Yates et al. 1993, Rainey et al. 2003, Deronde et al. 2006, Van der Wal \& Herman 2007) and microphytobenthos biomass (Méléder et al. 2003, Combe et al. 2005). So far, only few studies have used remotely sensed data to subsequently predict the occurrence of benthic macrofauna on an intertidal flat (Yates et al. 1993, Van der Wal et al. 2004).

In this study, we investigate which variables contribute to the spatial distribution and dynamics of macrobenthos on an intertidal flat. Response models are applied as a tool to explain and predict the spatiotemporal distribution of intertidal benthic macrofauna, using both time series of in situ data and synoptic remote sensing-derived data.

\section{MATERIALS AND METHODS}

Study site. The study was conducted in the Westerschelde, a coastal plain estuary in the southwest of the Netherlands (Fig. 1). The well-mixed macrotidal estuary experiences a semi-diurnal tide, and is nutrient rich and heterotrophic (Meire et al. 2005). The estuary is characterised by a complex network of flood and ebb channels surrounding intertidal flats. The study focused on the Plaat van Walsoorden $\left(51.4^{\circ} \mathrm{N}, 4.1^{\circ} \mathrm{E}\right)$, an intertidal flat in the mesohaline part of the estuary, with salinities typically ranging from ca. 14 to 17 , depending on tidal conditions and on river discharge. The tidal flat is ca. $4 \mathrm{~km}$ in length and $3 \mathrm{~km}$ in width, and is composed of sandy to muddy sediment, partly covered by microphytobenthos (mostly diatoms). On the highest parts of the flat, saltmarsh vegetation has established, dominated by either common cord grass Spartina anglica and sea aster Aster tripolium, or the annual glasswort Salicornia sp.

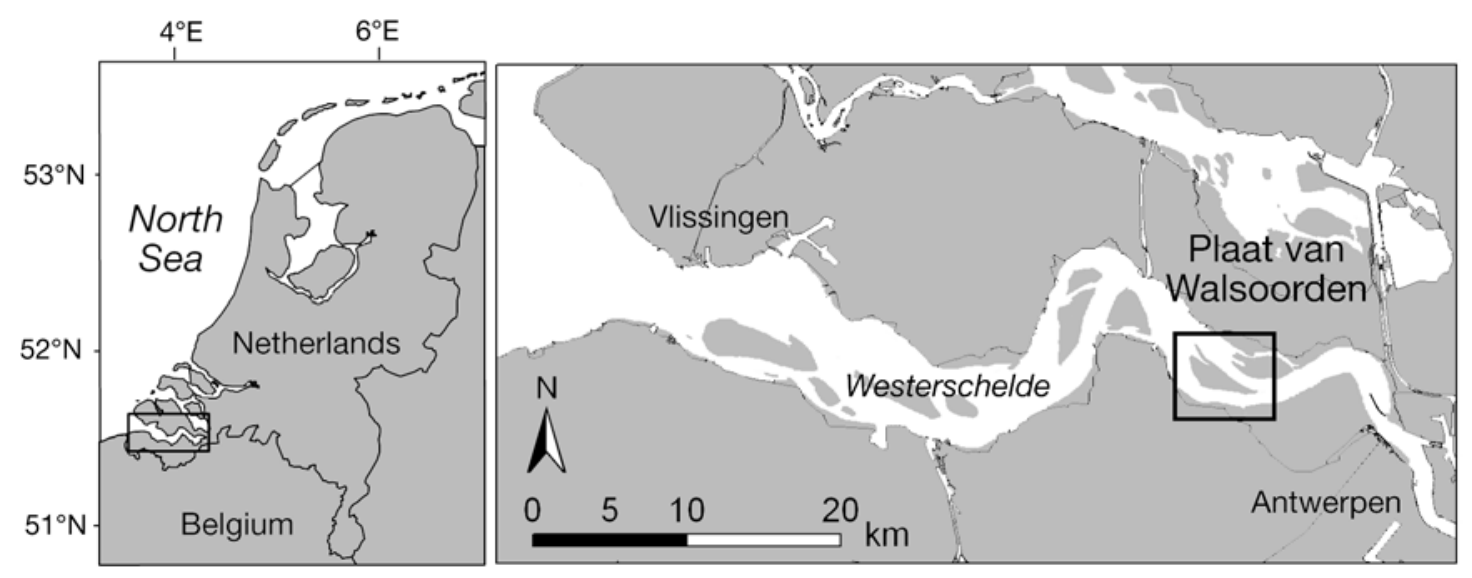

Fig. 1. Study site, Plaat van Walsoorden, southwest Netherlands 
Field sampling and laboratory analysis. Intensive field campaigns were carried out in spring (April or May) and autumn (September or late August) 2004, 2005, and 2006 to determine changes in macrobenthos and sediment grain size. Additional samples and reflectance spectra were taken during overpass of the airborne sensors in 2006. Samples were repeatedly collected on a fixed grid with 40 sample stations covering the entire intertidal flat. One station at the edge of the intertidal flat was abandoned in 2006 due to lateral erosion, and replaced by a new station nearby; the 2 stations were treated as separate stations. A GPS was used for positioning of the stations with ca. $5 \mathrm{~m}$ accuracy.

Macrobenthos: At each station, a core of $176.6 \mathrm{~cm}^{2}$ was collected up to a depth of $30 \mathrm{~cm}$ and the material $>1 \mathrm{~mm}$ was stained and fixed in formaldehyde. In the laboratory, all benthic invertebrates were picked out under a dissecting microscope, and counted and identified at species level. Fragmented animals were counted as one, and only the heads of fragmented polychaetes were counted. The animals were dried at $80^{\circ} \mathrm{C}$ for $2 \mathrm{~d}$, then at $100^{\circ} \mathrm{C}$ for $1 \mathrm{~d}$ and then ashed for $2 \mathrm{~h}$ at $580^{\circ} \mathrm{C}$ to determine biomass (ash-free dry weight, in $\mathrm{mg} \mathrm{m}^{-2}$ ). For bivalves, shell length was measured and converted into ash-free dry weight using length-weight regressions obtained for the same species, season and estuary. For fragments of bivalves, crabs and starfish, conversion factors of the wet weight were used. Density of all species was expressed in number of individuals per $\mathrm{m}^{2}$, and species richness as the number of species per sample. Shannon diversity index $H^{\prime}$, based on the natural logarithm (base e), and Pielou's evenness (equitability) index $J$ were calculated from density data (Zar 1999) using the software package PRIMER (Clarke \& Warwick 2001).

The animals were also classified at trophic group level, i.e. deep deposit feeders (including abundant species such as the polychaetes Heteromastus filiformis, Pygospio elegans and Arenicola marina [lugworm]), surface deposit feeders (including the amphipods Bathyporeia pilosa, Corophium arenaria, and Corophium volutator [mud shrimp], the gastropod Hydrobia ulvae [mud snail], and the bivalves Macoma balthica [Baltic tellin] and Scrobicularia plana [peppery furrow shell]), suspension feeders (including the bivalves Mya arenaria [soft-shell clam] and Cerastoderma edule [common cockle], the polychaete Polydora ligni and the amphipod Haustorius arenarius), predators (including the isopod Eurydice pulchra and the polychaete Eteone longa) and omnivores (including the polychaete Nereis diversicolor [ragworm]), based on literature (e.g. Fauchald \& Jumars 1979, Lopez \& Levinton 1987, Pearson 2001).
Sediment grain size: Samples of $20 \mathrm{~cm}^{3}$ were taken from the upper $3 \mathrm{~cm}$ of the sediment. They were freeze-dried and sieved in the laboratory. Material $<1 \mathrm{~mm}$ was analysed using a Malvern Mastersizer 2000, capable of detecting the $0.02 \mu \mathrm{m}$ to $1 \mathrm{~mm}$ grain size range, to derive values for mud content (percentage of the particles smaller than $63 \mu \mathrm{m}$ ) and median grain size $d_{50 \text {, in situ }}($ in $\mu \mathrm{m})$. No sediment data were available for spring 2004.

Chlorophyll a: During the field campaigns in 2006, additional samples were collected by mixing 3 samples (total surface area $4 \mathrm{~cm}^{2}$ ) from the upper $1 \mathrm{~cm}$ of the sediment at the 40 stations. The samples were stored in the dark at $-80^{\circ} \mathrm{C}$. Pigments were extracted by taking $1 \mathrm{~g}$ of homogenized sediment added to $10 \mathrm{ml} 90 \%$ acetone. Mechanical disruption using a Bead Beater ensured an efficient release of pigment. Extracts were quantified using HPLC. Pigments were identified by a comparison of peaks and retention times with available standards; peaks at $664 \mathrm{~nm}$ were used for determination of chlorophyll a $(\mathrm{chl} a)$. Chl $a$ is used as a proxy for microphytobenthos biomass (Underwood \& Kromkamp 1999).

Reflectance spectra: A RAMSES radiometer (Trios $\mathrm{GmbH}$ ) was used to detect the reflectance of the sediment surface. It recorded radiance in the 320-950 nm range, sampling every $3.3 \mathrm{~nm}$ with $0.3 \mathrm{~nm}$ accuracy. The surface was viewed from nadir position, with a target size of $5 \mathrm{~cm}$ in diameter. Upwelling spectral radiance from the sediment surface and a clean white polystyrene plate were measured successively under similar illumination conditions. The latter was assumed to be equal to downwelling spectral irradiance (Kromkamp et al. 2006). Three replicates of the target and reference were made at each station. Surface reflectance was calculated as the ratio of upwelling radiance to downwelling irradiance for each wavelength. Instrument noise was accounted for by subtracting the dark signal from all spectral measurements. The spectra were averaged per station. A Normalised Differential Vegetation Index based on these ground reflectance measurements (NDVI $\left.{ }_{\text {grnd }}\right)$ was calculated using surface reflectance in the red $\left(R_{683 \mathrm{~nm}}\right)$ and near-infrared $\left(R_{866 \mathrm{~nm}}\right)$ :

$$
\mathrm{NDVI}_{\text {gind }}=\frac{\left(R_{866 \mathrm{~nm}}-R_{683 \mathrm{~nm}}\right)}{\left(R_{866 \mathrm{~nm}}+R_{683 \mathrm{~nm}}\right)}
$$

Vegetation (including saltmarsh macrophytes such as Spartina anglica, Aster tripolium and Salicornia sp., but also microphytobenthos) absorbs most of the incoming visible light (but notably in the red part of the spectrum), and reflects a large portion of the nearinfrared light, causing a decrease in $R_{683 \mathrm{~nm}}$ and an increase in $R_{866 \mathrm{~nm}}$. Thus, NDVI gives higher values with increasing vegetation biomass, cover or health 
(Tucker 1979). The 2 spectral bands $R_{683 \mathrm{~nm}}$ and $R_{866 \mathrm{~nm}}$ are chosen because they are affected by the absorption of chlorophyll in vegetation, whereas the contrast between vegetation and sediment is at a maximum.

Airborne surveys and image analysis. Hyperspectral imagery: Airborne hyperspectral images were collected on 8 June 2004 employing a Hymap sensor (Hyvista), on 27 June 2005 with a CASI-2 sensor (ITRES) and on 30 June 2006 with a CASI-3 sensor (ITRES) during low tide and clear sky conditions. Radiance was recorded in 18 bands or more, in a spectral range of 442 to $940 \mathrm{~nm}$. Direct georeferencing procedures were applied, using measurements of the position (by means of a GPS) and orientation parameters (by means of an Inertial Measurement Unit [IMU]), and the images were projected in the UTM (31N)/WGS84 coordinate system. The images were atmospherically corrected and converted to images of surface reflectance with MODTRAN-based software using information on water vapour and ozone concentration measured during overpass (Biesemans et al. 2007). The images had a spatial resolution of ca. 2 to $4 \mathrm{~m}$, but were all resampled to $4 \mathrm{~m}$ spatial resolution, applying a nearest neighbour algorithm.

Sequential maps of the vegetation index based on the airborne images $\left(\mathrm{NDVI}_{\text {air }}\right)$ were created using the software package Erdas Imagine Professional (Leica Geosystems); the calculation of $\mathrm{NDVI}_{\text {air }}$ was identical to that of $\mathrm{NDVI}_{\text {grnd }}$. The $\mathrm{NDVI}_{\text {air }}$ map of 2006 was validated using values of $\mathrm{NDVI}_{\text {grnd }}$ measured during overpass: correlation between the 2 was high $(\mathrm{r}=0.83$, $\mathrm{n}=34, \mathrm{p}<0.0001 ; 1: 1$ slope). Moreover, $\mathrm{NDVI}_{\text {air }}$ was a good proxy for chl a $(\mathrm{r}=0.71, \mathrm{n}=34, \mathrm{p}<0.0001)$. Field surveys showed that $\mathrm{NDVI}_{\mathrm{air}}$ was larger than 0.4 for saltmarsh macrophytes, and smaller than 0.4 for other intertidal areas.

The images were also used for mapping the median grain size and mud content of the sediment, following Van der Wal \& Herman (2007). The spectral signature in the visible and near-infrared (VNIR) part of the electromagnetic spectrum as detected by the airborne sensors depends on the mineralogy of the sediment, sediment grain size distribution, moisture conditions, amount of organic matter and chl $a$ and other pigments. On intertidal flats, surface reflectance generally decreases with increasing mud content and decreasing sediment grain size through most of the VNIR because of water absorption, as finer sediments are associated with higher contents of interstitial moisture. Note that mud content and median grain size are also very well related on the Plaat van Walsoorden $\left(R^{2}=0.81, n=199\right.$, exponential relationship for all samples collected here).

Surface reflectance in each wavelength band was derived from each image at each sampling station.
In situ sediment grain size from samples collected in autumn was regressed against these surface reflectances in a stepwise forward multiple regression, followed by a stepwise backward multiple regression to retain the best fit, with the least number of bands (2 or 3 bands). As mud content is not linearly related to surface reflectances, mud percentages were transformed following arcsine $\sqrt{ }(x / 100)$. Sample points that did not have matching remote sensing data, and outliers (i.e. points with standard residuals $>2.5 \sigma$ ) were removed from the regression analysis. Regression results for the 2006 analysis were: $\mathrm{R}^{2}=0.82, \mathrm{SE}=0.11, \mathrm{n}=39, \mathrm{p}<$ 0.0001 for transformed mud content and $\mathrm{R}^{2}=0.60, \mathrm{SE}=$ $31.07, \mathrm{n}=39, \mathrm{p}<0.0001$ for median grain size. A similar performance was achieved for the 2004 data $\left(\mathrm{R}^{2}=\right.$ $0.75, \mathrm{SE}=0.09, \mathrm{n}=35, \mathrm{p}<0.0001$ for mud and $\mathrm{R}^{2}=$ 0.73, $\mathrm{SE}=20.44, \mathrm{n}=36, \mathrm{p}<0.0001$ for median grain size) and the 2005 data $\left(\mathrm{R}^{2}=0.82, \mathrm{SE}=0.09, \mathrm{n}=38, \mathrm{p}<\right.$ 0.0001 and $\mathrm{R}^{2}=0.70, \mathrm{SE}=23.42, \mathrm{n}=39, \mathrm{p}<0.0001$, respectively). The regression equations were then applied to the images to obtain maps of the 2 sediment grain size variables.

Laser altimetry: In April 2004, June 2005 and June 2006, Light Detection and Ranging (LIDAR) measurements were carried out using airborne equipment to quantify the elevation of the intertidal flat. These laser altimetry data were provided in a grid with a spatial resolution of $2 \mathrm{~m}$ (2004), or $1 \mathrm{~m}$ (2005 and 2006), and had a vertical accuracy $(1 \sigma)$ of $0.05 \mathrm{~m}$. Heights were converted in meters relative to the Dutch ordnance datum Normaal Amsterdams Peil (NAP), which is about mean sea level.

Statistical analysis and modelling. GIS analysis: At the 40 fixed sampling stations, values for the environmental variables were extracted from the maps derived from remote sensing in GIS. These data were combined with the sample database. It was assumed that the values derived from remote sensing were representative for that specific year.

ANOVA of univariate data: Mean effects ANOVA was carried out in Statistica (Statsoft) to test whether the variation in macrobenthos and environmental variables depended on the categorical predictors year, season, and sampling station, and the interaction term year $\times$ season. Sampling station was identified as a random effect in the analysis. To warrant homogeneity of variance, some variables were transformed, i.e. $\ln (x+1)$ for biomass and density of macrobenthos, with the arbitrary value of 1 added to avoid taking the natural logarithm of 0 for samples without macrobenthos. NDVI was transformed following $\ln (x+0.01)$. In this case, a smaller arbitrary offset (i.e. 0.01) was chosen, because the values of NDVI are small (in this case $0.00<\mathrm{NDVI}<0.57)$. Values for the mud percentage were transformed following arcsine $\sqrt{ }(x / 100)$. 
Multivariate analysis: Temporal changes in the composition of the macrobenthos community were analysed based on log-transformed biomass and density $(\ln [x+1])$ of the macrobenthos species using the software package PRIMER (Clarke \& Warwick 2001). Samples that contained only 1 or no species were omitted. Similarity matrices and cluster groups were generated for each year and season of sampling, based on the Bray-Curtis similarity index. Significance of differences in macrobenthos community between years and seasons was formally tested using ANOSIM. SIMPER analysis identified which species were responsible for the distinction of groups.

Univariate regression analysis: A generalized linear model (GLM) based on maximum likelihood estimation was applied in the statistical environment $\mathrm{R}$ to test the response of macrobenthos to the environmental variables. Macrobenthos biomass or species richness was expressed as a polynomial function (linear predictor) of the independent environmental variables, including $\mathrm{NDV}_{\text {air }}$ and elevation from remote sensing, and median grain size and mud content of the sediment from sampling, using a Gamma error distribution and an inverse link function. As this type of GLM requires a positive response variable, an arbitrary value of 1 was added to biomass and species richness. A transformation of $\ln (x+0.01)$ was applied to $\mathrm{NDVI}_{\text {air }}$, and a transformation of arcsine $\sqrt{ }(x / 100)$ was applied to mud percentages, consistent with the transformations used in the ANOVA analysis. Cases with information on all variables ( $\mathrm{n}=$ 196) were used in the modelling. Models with different combinations of variables and their interaction terms were evaluated. The trade-off between goodness-of-fit and parsimony of the models was compared using Akaike's Information Criterion (AIC) (Sakamoto et al. 1986); smaller values of the AIC indicate a better model. In addition, $D^{2}$ adj was calculated for each model as an estimate of deviance reduction, adjusted for the available degrees of freedom, analogous to $R_{\text {adj }}^{2}$ in least-squares regression (Guisan \& Zimmerman 2000). Robustness and ranking of the models was confirmed by repeating the analysis with randomly chosen subsets, including $75 \%(\mathrm{n}=147)$ of the total data set in each run, and by repeating the analysis with subsets from separate years.

Macrobenthos mapping: The best response models (i.e. models with lowest AIC) were applied to the maps of the environmental variables derived from airborne remote sensing using the Erdas Imagine Modeller. This yielded a prediction of the spatial distribution of the biomass of the macrobenthos. Predictions were evaluated by regressing the observed untransformed biomass sampled in autumn against the predicted untransformed biomass at the 40 stations. One or 2 outliers were removed from analysis; these were sample points with standard residuals $>2.5 \sigma$.

\section{RESULTS}

\section{Distribution and dynamics of macrobenthos from sampling}

Consistent patterns were found for the distribution of macrobenthos sampled in autumn. Highest total biomass, density and species richness was observed near the centre of the intertidal flat, whereas lowest biomass, density and species richness was found on the northern spit (Fig. 2). A small increase in species richness with time was observed in a number of places in the centre and edges of the tidal flat, and on the northern spit (Fig. 2c), indicating changes in species richness at the scale of the tidal flat, rather than the station scale. Indeed, when counting species in all samples collected per year (spring and autumn), 30 species were found in 2004, 34 species in 2005 and 41 species in 2006.

During the study, biomass of macrobenthos $\left(F_{2,194}=\right.$ $0.43, \mathrm{p}=0.649)$ and density of macrobenthos $\left(F_{2,194}=\right.$ $0.34, \mathrm{p}=0.712$ ) did not change significantly (Table 1). Species richness increased significantly $\left(F_{2,194}=6.93, \mathrm{p}=0.001\right)$, but the increase in species diversity $\mathrm{H}^{\prime}\left(F_{2,194}=1.33, \mathrm{p}=0.267\right)$ and evenness $J^{\prime}$ $\left(F_{2,178}=0.504, \mathrm{p}=0.605\right)$ was not significant (Table 1). Macrobenthos had significantly higher biomass $\left(F_{1,194}=10.17, \mathrm{p}=0.002\right)$ and density $\left(F_{1,194}=\right.$ 5.67, $\mathrm{p}=0.018)$ in autumn than in spring. Species richness $\left(F_{1,194}=17.08, \mathrm{p}<0.001\right)$ and species diversity $H^{\prime}\left(F_{1,194}=9.73, \mathrm{p}=0.002\right)$ were also significantly higher in autumn than in spring, whereas the evenness $J$ did not change significantly $\left(F_{1,178}=0.023\right.$, $\mathrm{p}=0.881)$.

There were significant changes in the composition of the macrobenthos community, albeit with a very large overlap in species (ANOSIM, global-R $=0.018$, $\mathrm{p}=0.011$ for biomass, and global- $\mathrm{R}=0.025, \mathrm{p}=0.004$ for density). Firstly, there were significant seasonal differences in the macrobenthos community (ANOSIM, all $\mathrm{p}<0.05$ ). Secondly, there were significant differences in macrobenthos community in 2004 versus $2005(\mathrm{R}=0.015, \mathrm{p}=0.046$ for biomass and $\mathrm{R}=$ $0.022, \mathrm{p}=0.0023$ for density), and 2004 versus 2006 $(\mathrm{R}=0.028, \mathrm{p}=0.006, \mathrm{R}=0.041, \mathrm{p}=0.002)$. No significant differences were found between 2005 and 2006 $(\mathrm{R}=0.014, \mathrm{p}=0.069, \mathrm{R}=0.012, \mathrm{p}=0.094)$. The differences in macrobenthos community between 2004 and 2005 were mainly attributed to an increase in biomass and density of Pygospio elegans, Nereis diversicolor, Oligochaeta and a decrease in Bathyporeia pilosa. The differences between 2004 and 2006 were caused by an increase in $N$. diversicolor, Heteromastus filiformis and Macoma balthica and a decrease in B. pilosa. 
(a)

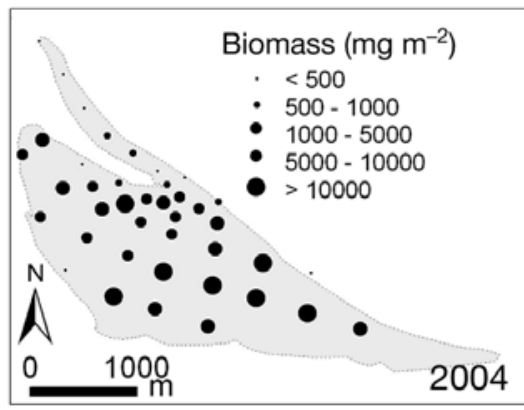

(b)

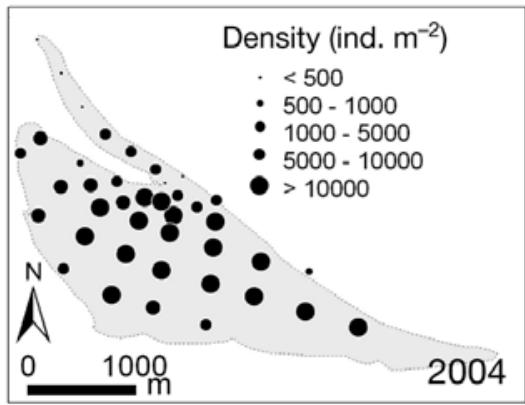

(c)

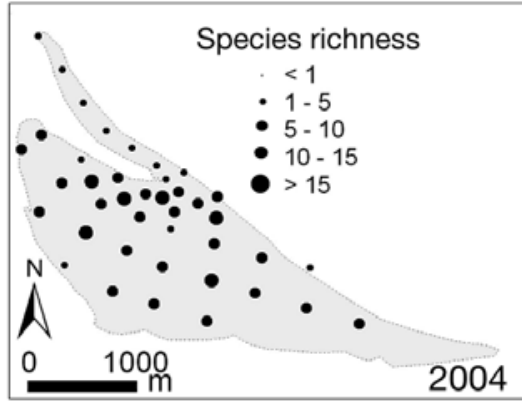

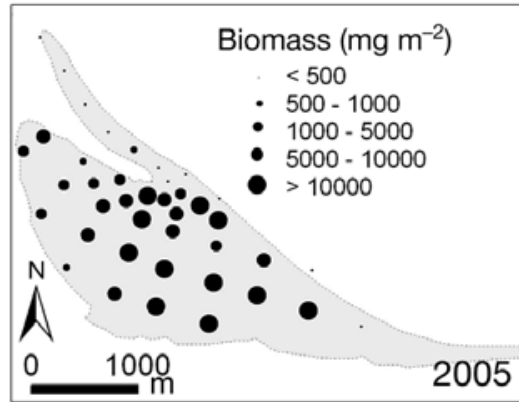
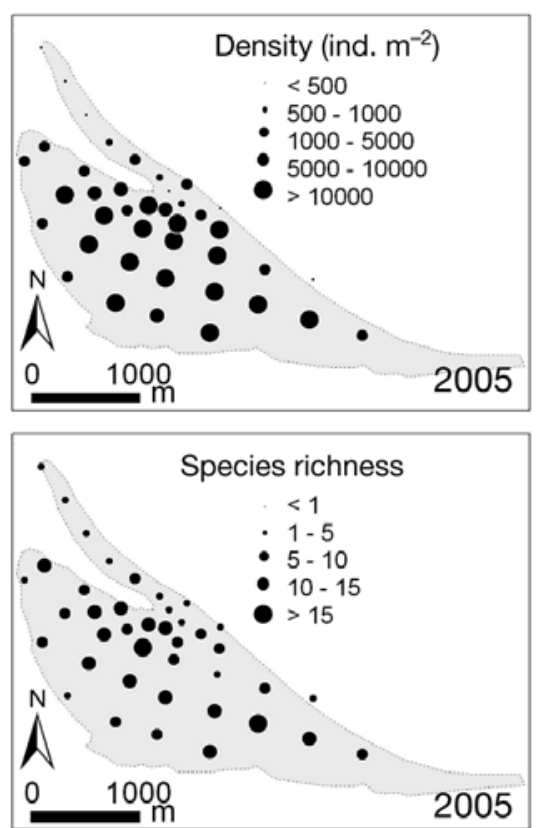
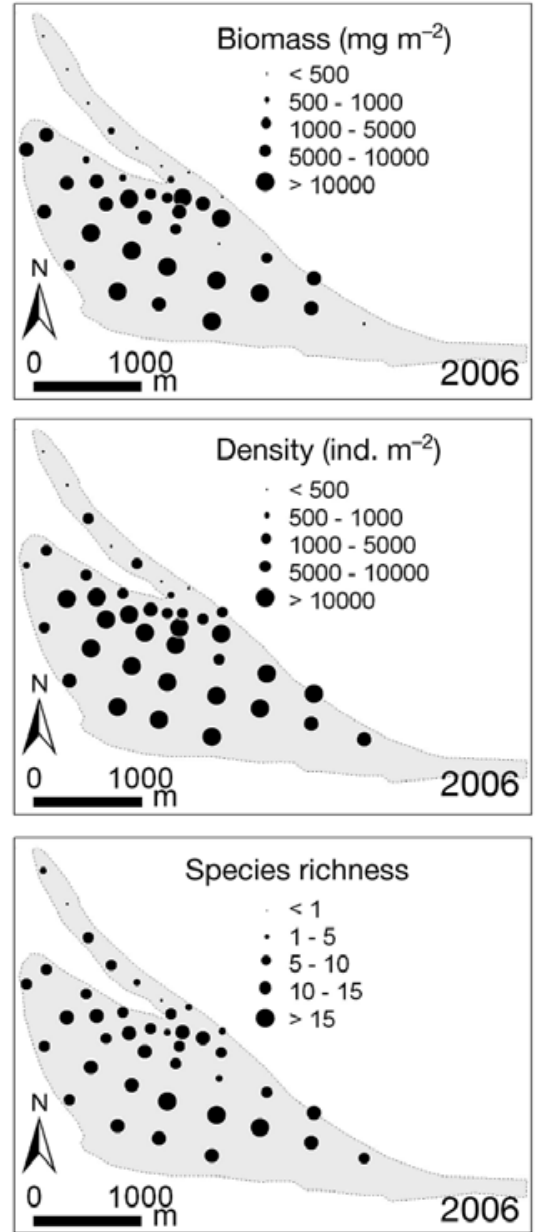

Fig. 2. Spatial distribution of the macrobenthos for consecutive autumns. (a) Total area average macrobenthos biomass, (b) total area average macrobenthos density and (c) total area average species richness

Table 1. Macrobenthos and environmental variables in the $3 \mathrm{yr}$ study period. See 'Materials and methods' for dates of in situ sampling and remote sensing image acquisition

\begin{tabular}{|c|c|c|c|c|c|c|}
\hline & $\begin{array}{r}2004 \\
\text { Mean } \pm \text { SE }\end{array}$ & $\mathrm{n}$ & $\begin{array}{r}2005 \\
\text { Mean } \pm \text { SE }\end{array}$ & $\mathrm{n}$ & $\begin{array}{c}2006 \\
\text { Mean } \pm \text { SE }\end{array}$ & $\mathrm{n}$ \\
\hline \multicolumn{7}{|l|}{ In situ } \\
\hline Macrobenthos biomass $\left(\mathrm{mg} \mathrm{m}^{-2}\right)$ & $3702 \pm 446$ & 80 & $5029 \pm 628$ & 80 & $5613 \pm 759$ & 80 \\
\hline Macrobenthos density (ind. $\mathrm{m}^{-2}$ ) & $8841 \pm 1144$ & 80 & $12268 \pm 1836$ & 80 & $13935 \pm 2192$ & 80 \\
\hline Species richness (no. sample ${ }^{-1}$ ) & $5.86 \pm 0.31$ & 80 & $6.85 \pm 0.40$ & 80 & $7.18 \pm 0.45$ & 80 \\
\hline Shannon-Wiener diversity index $H^{\prime}$ & $0.93 \pm 0.05$ & 80 & $0.98 \pm 0.05$ & 80 & $1.04 \pm 0.06$ & 80 \\
\hline Pilou's evenness (equitability) index $J^{\prime}$ & $0.59 \pm 0.02$ & 74 & $0.60 \pm 0.02$ & 75 & $0.62 \pm 0.03$ & 75 \\
\hline Median grain size $(\mu \mathrm{m})$ & $179.02 \pm 6.11$ & 39 & $175.45 \pm 4.49$ & 80 & $171.88 \pm 4.95$ & 80 \\
\hline Mud $(\%)$ & $4.82 \pm 1.18$ & 39 & $5.64 \pm 1.07$ & 80 & $7.10 \pm 1.29$ & 80 \\
\hline Chl a $\left(\mu g g^{-1}\right)$ & - & - & - & - & $11.91 \pm 2.25$ & 80 \\
\hline Vegetation index $\mathrm{NDVI}_{\text {grnd }}$ & - & - & - & - & $0.15 \pm 0.01$ & 66 \\
\hline \multicolumn{7}{|l|}{ Remote sensing } \\
\hline Vegetation index $\mathrm{NDVI}_{\mathrm{air}}$ & $0.11 \pm 0.01$ & 37 & $0.16 \pm 0.02$ & 39 & $0.15 \pm 0.02$ & 39 \\
\hline Median grain size $(\mu \mathrm{m})$ & $180.78 \pm 5.58$ & 37 & $171.04 \pm 5.62$ & 39 & $169.35 \pm 6.12$ & 39 \\
\hline Mud (\%) & $4.35 \pm 1.04$ & 37 & $5.87 \pm 1.39$ & 39 & $7.41 \pm 1.47$ & 39 \\
\hline Elevation (m NAP) & $0.73 \pm 0.19$ & 39 & $0.88 \pm 0.19$ & 39 & $0.90 \pm 0.18$ & 39 \\
\hline
\end{tabular}


Distribution and dynamics of environmental variables from sampling and remote sensing

The distribution of the 4 environmental variables obtained from remote sensing and in situ sampling also showed distinct, repeatable patterns in time and space (Fig. 3). The highest values for $\mathrm{NDVI}_{\text {air }}$ occurred near the centre of the intertidal flat. These areas also had the finest sediment (lowest grain size and highest mud content) and were the most elevated. The northern spit, in contrast, had the lowest values for $\mathrm{NDVI}_{\text {air }}$ coarsest sediment, and was situated lowest.

There was a significant difference in $\mathrm{NDVI}_{\text {air }}$ between years $\left(F_{2,74}=8.27, \mathrm{p}=0.001\right)$ due to an increase in microphytobenthos biomass between June 2004 and June 2005 only (Table 1). This increase can also be seen on the sequential maps of $\mathrm{NDVI}_{\text {air }}$ (Fig. 3). Between 2005 and 2006, a decrease in area with inter- (a)

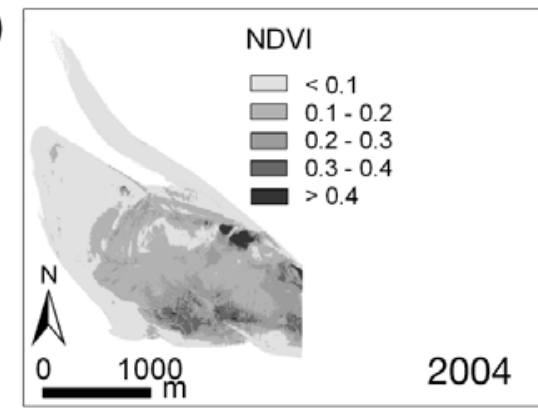

(b)

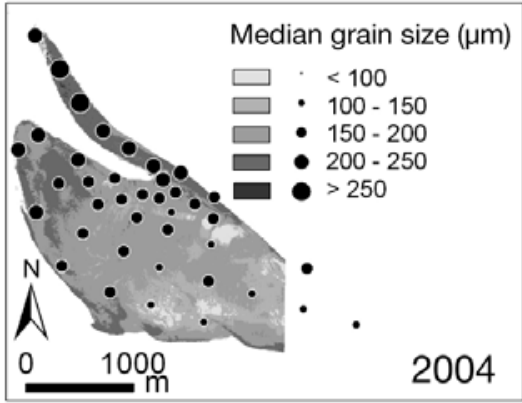

(c)

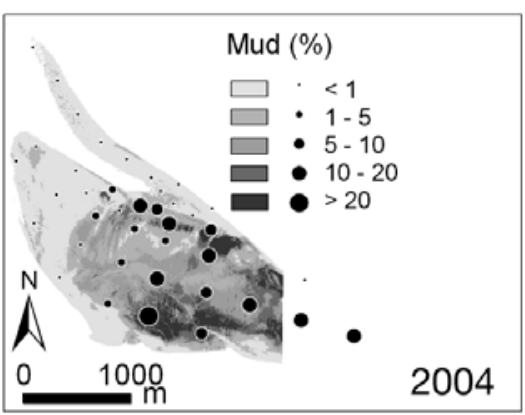

(d)

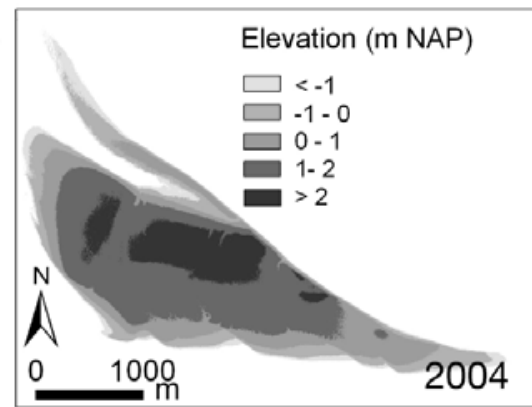

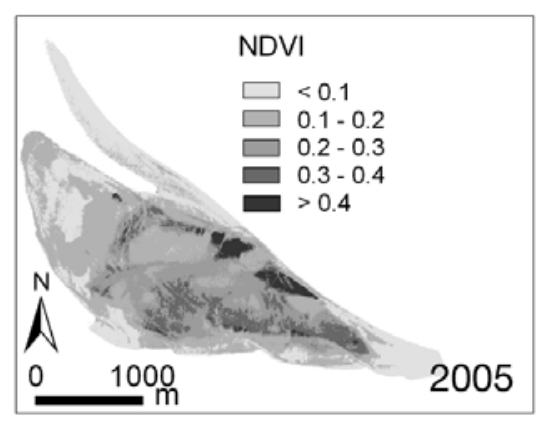
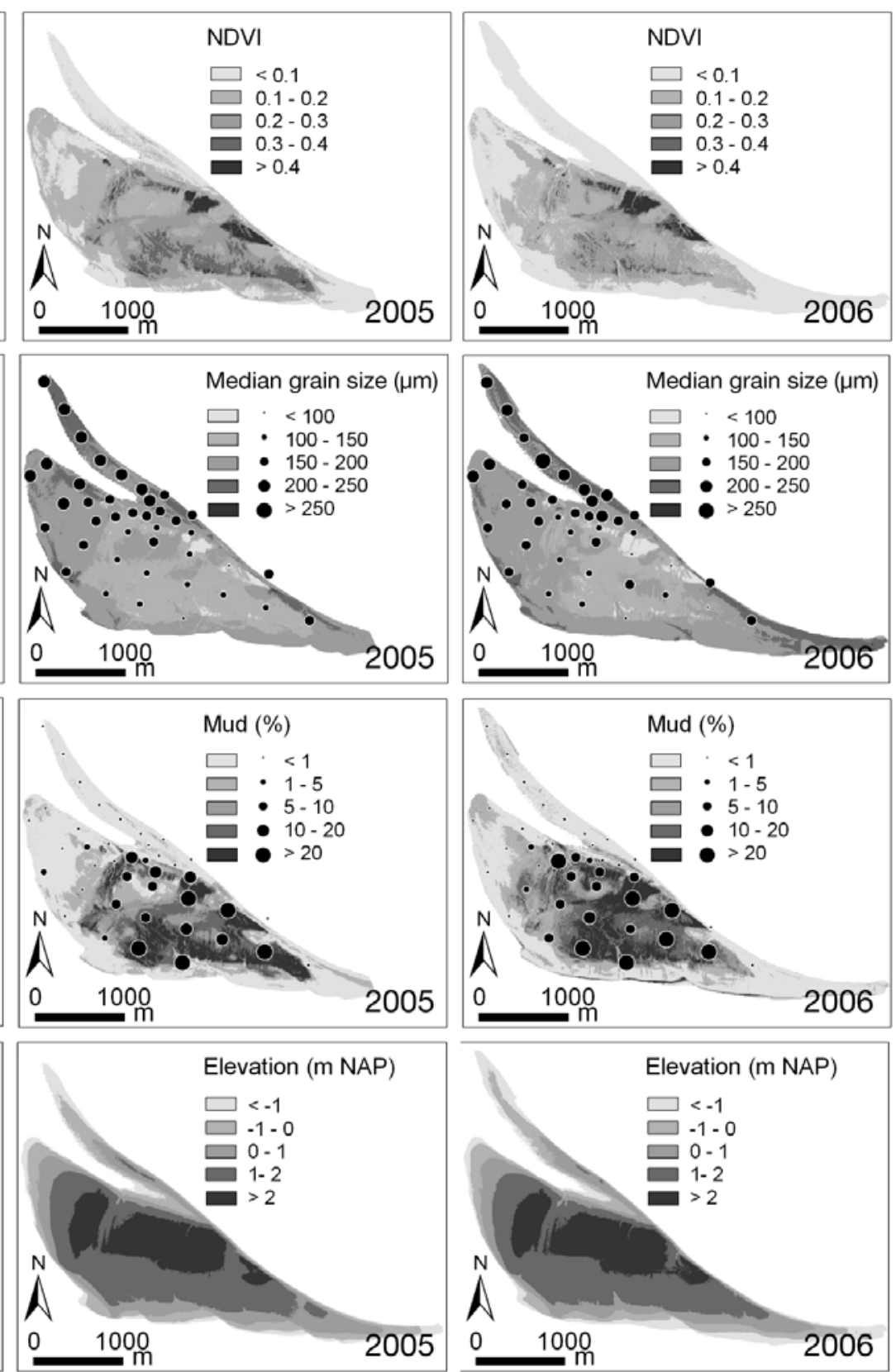

Fig. 3. Spatial distribution of the environmental variables. (a) Vegetation index NDVI, (b) median grain size, (c) mud content of the sediment and (d) elevation (NAP: Normaal Amsterdams Peil chart datum; ca. mean sea level). Shading: remote sensingderived information; $\bullet$ : information from in situ sampling 
mediate $\mathrm{NDVI}_{\text {air }}$ is apparent, whereas the saltmarsh areas $\left(\mathrm{NDVI}_{\mathrm{air}}>0.4\right)$ have expanded. The sediment characteristics also varied in time (Table 1). A significant decrease in in situ median grain size $\left(F_{2,154}=4.3\right.$, $\mathrm{p}=0.015)$ was observed, whereas in situ mud content had not changed significantly $\left(F_{2,154}=2.51\right.$, $\left.\mathrm{p}=0.085\right)$. Seasonal variations of in situ sediment grain size were significant $\left(F_{2,154}=8.23, \mathrm{p}=0.005\right.$ for median grain size and $F_{2,154}=8.76, \mathrm{p}=0.004$ for mud content), with samples in autumn finer than samples in spring. The remote sensing derived maps confirmed the observed interannual fining of the sediment $\left(F_{2,74}=6.08, \mathrm{p}=\right.$ 0.004 for remote sensing derived median grain size and $F_{2,74}=7.25, \mathrm{p}=0.001$ for remote sensing derived mud content). Predicted sediments from remote sensing images were finer than yearly averages of in situ samples for 2005 and 2006 (Table 1), as the predicted maps were based on summer/autumn data only. Laser altimetry surveys showed a gradual and significant $\left(F_{2,77}=13.8, \mathrm{p}<0.0001\right)$ increase in mean shore elevation (Table 1).

\section{Prediction of macrobenthos distribution from environmental variables}

Response curves have been constructed to identify the environmental variables that influence the biomass and species richness of macrobenthos. Total macrobenthos biomass can be explained by the models using median grain size (model TB2) (Table 2), mud content (model TB3) or elevation (model TB4), but mostly by NDVI $_{\text {air }}$ (model TB1). However, the best prediction (i.e. the model with lowest AIC value) of total macrobenthos biomass was the model with both $\mathrm{NDVI}_{\text {air }}$ and median grain size as explanatory variables (model TB5). This model explained $34 \%$ of the deviance. Biomass of total benthic macrofauna increased with $\mathrm{NDVI}_{\text {air }}$ except for the highest $\mathrm{NDVI}_{\text {air }}$ values (which corresponded to saltmarsh areas), and with median grain size, with an optimum biomass at a grain size of ca. $100 \mu \mathrm{m}$ (Fig. 4). Similar results were obtained for species richness as a function of the environmental variables (Table 2).

The main functional groups each have a different response to the environmental variables (Table 3). Of all 4 environmental variables, the deposit feeders responded strongest to median grain size (model DF2), but the best prediction of the biomass of deposit feeders was the model including $\mathrm{NDVI}_{\text {air, }}$ median grain size of the sediment and elevation (model DF5), although only $13 \%$ of the deviance was explained by this model. Surface deposit feeders responded strongest to $\mathrm{NDVI}_{\text {air }}$ (model SDF1), but the best model included both $\mathrm{NDVI}_{\text {air }}$ and median grain size (model SDF5), explaining $22 \%$ of the deviance. For suspension feeders, the model based on a combination of $\mathrm{NDVI}_{\text {air }}$ and median grain size was best (model SF5). However, this model explained only $10 \%$ of the deviance, and none of the terms in the model were significant ( $p>0.09)$.

Responses were also constructed for 4 individual macrobenthos species (Table 4, Figs. 5 to 8). The 4 species were selected because they had contributed most significantly to the changes in species composition as identified by the multivariate analysis, and were rela-

Table 2. Response of total macrobenthos biomass and species richness to the environmental variables log-transformed vegetation index NDVI derived from airborne remote sensing, in situ median grain size $\left(d_{50}\right)$, and transformed in situ mud content $(M)$, and remote sensing derived elevation $(z)$. Transformed biomass is a function of $1 \mathrm{lp}^{-1}$. Significance of terms $\left({ }^{*} \mathrm{p}<0.05,{ }^{* *} \mathrm{p}<0.01\right.$, $\left.{ }^{* * *} \mathrm{p}<0.001\right)$, goodness-of-fit $D^{2}$ adj and the AIC are given, with AIC of the best model in bold. Only models with 1 variable and the best 2 complex models (i.e. models with the lowest AIC) are shown

\begin{tabular}{|c|c|c|c|c|}
\hline Group & Model & Linear predictor (lp) & $D_{\text {adj }}^{2}$ & AIC \\
\hline \multirow{6}{*}{$\begin{array}{l}\text { Total } \\
\text { biomass }\end{array}$} & TB1 & $\left(9.692 \times 10^{-4}\right) \mathrm{NDVI}^{* * *}+\left(3.219 \times 10^{-4}\right) \mathrm{NDVI}^{2 * * *}+\left(8.226 \times 10^{-4}\right)^{* * *}$ & 0.28 & 3619.1 \\
\hline & TB2 & $\left(-1.151 \times 10^{-5}\right) d_{50}^{* * *}+\left(4.985 \times 10^{-8}\right) d_{50^{2 * * *}}+\left(7.393 \times 10^{-4}\right)^{* *}$ & 0.24 & 3632.6 \\
\hline & TB3 & $-0.00142 M^{* * *}+0.00154 M^{2 * * *}+0.000406$ & 0.19 & 3648.9 \\
\hline & TB4 & $\left(6.179 \times 10^{-5}\right) z^{* * *}-\left(2.036 \times 10^{-4}\right) z^{2 * *}+\left(3.049 \mathrm{E}-4 \times 10^{-4}\right)^{* * *}$ & 0.10 & 3673.4 \\
\hline & TB5 & $\begin{array}{l}\left(8.409 \times 10^{-4}\right) \mathrm{NDVI}^{* * *}+\left(2.471 \times 10^{-4}\right) \mathrm{NDVI}^{2 * * *}-\left(5.247 \times 10^{-6}\right) d_{50}+ \\
\quad\left(2.582 \times 10^{-8}\right) d_{50}{ }^{2 *}+0.001024^{* * *}\end{array}$ & 0.34 & 3601.0 \\
\hline & TB6 & $\begin{array}{l}\left(8.639 \times 10^{-4}\right) \mathrm{NDVI}^{* * *}+\left(2.550 \times 10^{-4}\right) \mathrm{NDVI}^{2 * * *}-\left(8.010 \times 10^{-6}\right) d_{50}{ }^{*}+ \\
\left(3.638 \times 10^{-8}\right) d_{50^{2 * *}}+\left(7.327 \times 10^{-5}\right) z-\left(2.061 \times 10^{-5}\right) z^{2}+0.001158^{* * *}\end{array}$ & 0.34 & 3601.4 \\
\hline \multirow{6}{*}{$\begin{array}{l}\text { Species } \\
\text { richness }\end{array}$} & SR1 & $0.0514 \mathrm{NDVI}^{*}+0.0217 \mathrm{NDVI}^{2 * * *}+0.134^{* * *}$ & 0.31 & 990.1 \\
\hline & SR2 & $-0.00222 d_{50}^{* * *}+\left(9.458 \times 10^{-6}\right) d_{50}^{2 * * *}+0.222^{* * *}$ & 0.32 & 990.2 \\
\hline & SR3 & $-0.3014 M^{* * *}+0.337 M^{2 * * *}+0.1593^{* * *}$ & 0.19 & 1024.2 \\
\hline & SR4 & $-0.05051 z^{* * *}+0.01408 z^{2 * * *}+0.1516^{* * *}$ & 0.25 & 1009.9 \\
\hline & SR5 & $\begin{array}{l}\left(0.0926 \mathrm{NDVI}^{* * *}+0.0236 \mathrm{NDVI}^{2 * * *}-0.001152 d_{50}^{*}+\right. \\
\quad\left(5.869 \times 10^{-6}\right) d_{50}{ }^{2 * *}+0.2281^{* * *}\end{array}$ & 0.43 & 955.9 \\
\hline & SR6 & $\begin{array}{l}\text { 0.08931 NDVI } \mathrm{ND}^{* * *}+0.02267 \mathrm{NDVI}^{2 * * *}-0.00116 d_{50}+ \\
\left(5.853 \times 10^{-6}\right) d_{50}^{2 * *}-0.00445 z-0.00237 z^{2 * *}+0.227^{* * *}\end{array}$ & 0.42 & 959.4 \\
\hline
\end{tabular}



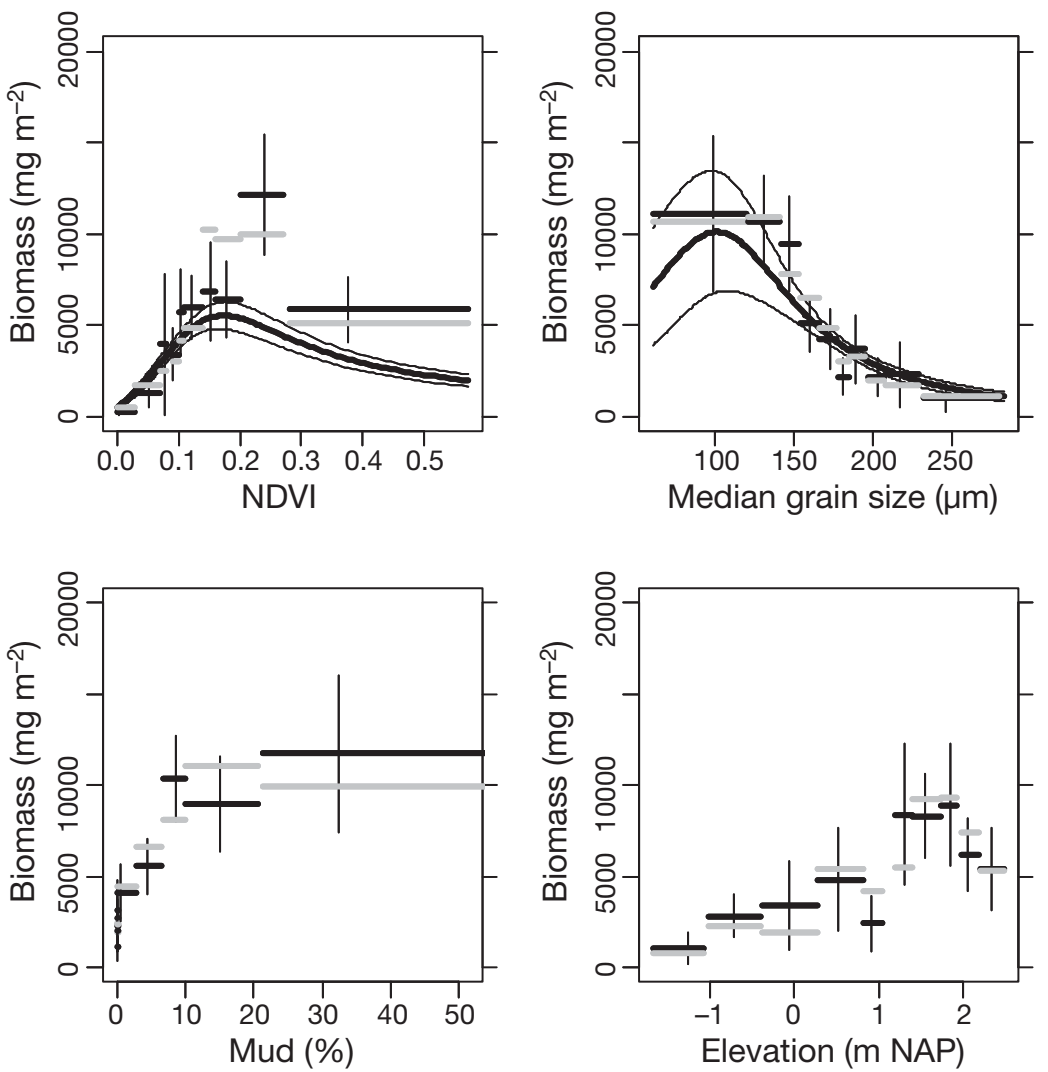

Fig. 4. Response of total biomass of benthic macrofauna as a function of the 4 environmental variables. A fit (一) with SE (-) is drawn for the combination of vegetation index NDVI and median grain size. The data are split into 10 classes of the environmental variable, with an equal number of observations in each class. (-): mean value per class; (|): 95\% confidence interval per class; (-): mean prediction for the fitted model per class. NAP: Normaal Amsterdams Peil, ca. mean sea level

Table 3. Response of the biomass of selected functional groups to the environmental variables log-transformed vegetation index NDVI derived from airborne remote sensing, in situ median grain size $\left(d_{50}\right)$, and transformed in situ mud content $(M)$, and remote sensing derived elevation $(z)$. Transformed biomass is a function of $1 \mathrm{lp}^{-1}$. Significance of terms $\left({ }^{*} \mathrm{p}<0.05,{ }^{* *} \mathrm{p}<0.01,{ }^{* * *} \mathrm{p}<\right.$ $0.001)$, goodness-of-fit $D^{2}$ adj and the AIC are given, with AIC of the best model in bold. Only models with 1 variable and the best 2 complex models are shown

\begin{tabular}{|c|c|c|c|c|}
\hline Functional group & Model & Linear predictor (lp) & $D_{\text {adj }}^{2}$ & AIC \\
\hline \multirow[t]{6}{*}{ Deposit feeders } & DF1 & $0.00557 \mathrm{NDVI}^{*}+0.00186 \mathrm{NDVI}^{2 *}+0.00464^{*}$ & 0.09 & 2386.4 \\
\hline & DF2 & $-\left(4.704 \times 10^{-5}\right) d_{50}+\left(2.37 \times 10^{-7}\right) d_{50}{ }^{2 *}+0.002605$ & 0.10 & 2384.9 \\
\hline & DF3 & $-0.009618 M^{* *}+0.00968 M^{2 *}+0.00271^{* * *}$ & 0.09 & 2387.9 \\
\hline & DF4 & $-\left(7.21 \times 10^{-4}\right) z+\left(2.37 \times 10^{-4}\right) z^{2}+0.00136^{* * *}$ & 0.01 & 2411.3 \\
\hline & DF5 & $\begin{array}{l}\text { 0.00457 NDVI }{ }^{*}+0.00135 \mathrm{NDVI}^{2 *}-\left(4.306 \times 10^{-5}\right) d_{50}+\left(2.213 \times 10^{-7}\right) d_{50}{ }^{2}+ \\
\quad\left(8.233 \times 10^{-4}\right) z^{*}-\left(3.080 \times 10^{-4}\right) z^{2}+0.00568\end{array}$ & 0.13 & 2376.8 \\
\hline & DF6 & $\begin{array}{l}0.00519 \mathrm{NDVI}^{*}+0.00152 \mathrm{NDVI}^{2 *}-0.0104 \mathrm{M}^{*}+0.0106 \mathrm{M}^{2}+ \\
0.001069 z^{*}-\left(3.702 \times 10^{-4}\right) z^{2}+0.006464^{* *}\end{array}$ & 0.13 & 2377.0 \\
\hline \multirow{6}{*}{$\begin{array}{l}\text { Surface deposit } \\
\text { feeders }\end{array}$} & SDF1 & $0.00250 \mathrm{NDVI}^{* * *}+\left(7.63 \times 10^{-4}\right) \mathrm{NDVI}^{2 * * *}+0.00225^{* * *}$ & 0.22 & 3305.7 \\
\hline & SDF2 & $-\left(2.464 \times 10^{-5}\right) d_{50}^{* *}+\left(9.430 \times 10^{-8}\right) d_{50}^{2 * *}+0.00182^{* *}$ & 0.11 & 3338.6 \\
\hline & SDF3 & $-0.00241 M^{* * *}+0.00325 M^{2 * * *}+\left(6.522 \times 10^{-4}\right)^{* * *}$ & 0.08 & 3347.3 \\
\hline & SDF4 & $-\left(3.414 \times 10^{-4}\right) z^{* *}+\left(1.066 \times 10^{-4}\right) Z^{2 *}+\left(5.236 \times 10^{-4}\right)^{* * *}$ & 0.05 & 3354.5 \\
\hline & SDF5 & $\begin{array}{l}0.002382 \mathrm{NDVI}^{* * *}+\left(6.865 \times 10^{-4}\right) \mathrm{NDVI}^{2 * * *}- \\
\quad\left(7.201 \times 10^{-6}\right) d_{50}+\left(3.162 \times 10^{-8}\right) d_{50}^{2}+0.00262^{* * *}\end{array}$ & 0.22 & 3304.9 \\
\hline & SDF6 & $\begin{array}{l}0.00240 \mathrm{NDVI}^{* * *}+\left(6.931 \times 10^{-4}\right) \mathrm{NDVI}^{2 * * *}-\left(1.265 \mathrm{E} \times 10^{-5}\right) d_{50}+ \\
\left(5.222 \times 10^{-8}\right) d_{50}^{2}+\left(9.251 \times 10^{-5}\right) z-\left(9.081 \times 10^{-6}\right) z^{2}+0.00286^{* * *}\end{array}$ & 0.22 & 3306.0 \\
\hline \multirow[t]{6}{*}{ Suspension feeders } & SF1 & $0.08323 \mathrm{NDVI}+0.02507 \mathrm{NDVI}^{2}+0.07496$ & 0.09 & 1481.3 \\
\hline & SF2 & $-\left(3.44 \times 10^{-4}\right) d_{50}+\left(1.029 \times 10^{-6}\right) d_{50}^{2}+0.03917$ & 0.00 & 1510.5 \\
\hline & SF3 & $-0.06412 M+0.1223 M^{2}+0.01558^{*}$ & 0.01 & 1505.8 \\
\hline & SF4 & $-0.00531 z+0.00248 z^{2}+0.01226$ & 0.01 & 1508.6 \\
\hline & SF5 & $\begin{array}{l}0.0724 \mathrm{NDVI}+0.0243 \mathrm{NDVI}^{2}-\left(2.749 \times 10^{-5}\right) d_{50}- \\
\left(2.765 \times 10^{-7}\right) d_{50}^{2}+0.07145\end{array}$ & 0.10 & 1478.9 \\
\hline & SF6 & $\begin{array}{l}0.07358 \mathrm{NDVI}+0.0239 \mathrm{NDVI}^{2}-\left(2.056 \times 10^{-4}\right) d_{50}-\left(3.561 \times 10^{-8}\right) d_{50}{ }^{2}- \\
0.03792 \mathrm{M}+0.02807 \mathrm{M}^{2}+0.1032\end{array}$ & 0.10 & 1480.9 \\
\hline
\end{tabular}


tively abundant in samples. Heteromastus filiformis was preferably found in muddy sediments (ca. 25\% mud, $d_{50} \approx 100 \mu \mathrm{m}$ ), with relatively large values for $\mathrm{NDVI}_{\text {air }}(\mathrm{NDVI} \approx 0.25)$. The highest biomass of Bathyporeia pilosa was found in coarse sediment $\left(d_{50} \approx\right.$ $200 \mu \mathrm{m}$ ) with low values of $\mathrm{NDVI}_{\text {air }}(\mathrm{NDVI} \approx 0.07$ ). Pygospio elegans had an intermediate response, with an optimum of $d_{50} \approx 150 \mu \mathrm{m}$, mud $\approx 10 \%$ and NDVI $\approx$ 0.2 , and an optimum elevation at ca. $2.0 \mathrm{~m}$ NAP. Nereis diversicolor attained its maximum biomass in finer sediments $\left(d_{50} \approx 125 \mu \mathrm{m}\right.$, mud $\left.\approx 25 \%\right)$, and lower elevations $(z \approx 1.5 \mathrm{~m}$ NAP). For all species, a complex response model was best at explaining the distribution of biomass (Table 4). Overall performance of the best response models for each species (i.e. models HF6,
BP5, ND5 and PE6) was worst for $H$. filiformis (explaining $12 \%$ of the deviance), and best for B. pilosa and $P$. elegans (explaining $42 \%$ and $44 \%$, respectively).

These best species response models were applied to the synoptic maps of the environmental variables derived from the airborne remote sensing images of 2006, to predict the spatial distribution of the biomass of the species (Fig. 9). High biomasses of Heteromastus filiformis, Nereis diversicolor and Pygospio elegans were especially predicted for the centre of the intertidal flat, whereas Bathyporeia pilosa was predicted to reach its highest biomass at the edges, corresponding to their observed distribution. All maps, including maps of total biomass and species richness, showed significant predictions (Table 5). Similar results were achieved when the

Table 4. Response of the biomass of key species to the environmental variables log-transformed vegetation index NDVI derived from airborne remote sensing, in situ median grain size $\left(d_{50}\right)$, and transformed in situ mud content $(M)$, and remote sensing derived elevation $(z)$. Transformed biomass is a function of $1 \mathrm{lp}^{-1}$. Significance of terms $\left({ }^{*} \mathrm{p}<0.05,{ }^{* *} \mathrm{p}<0.01,{ }^{* * *} \mathrm{p}<0.001\right)$, goodness-of-fit $D^{2}$ adj and the AIC are given, with AIC of the best model in bold. Only models with 1 variable and the best 2 complex models are shown

\begin{tabular}{|c|c|c|c|c|}
\hline Species & Model & Linear predictor (lp) & $D^{2}{ }_{\text {adj }}$ & AIC \\
\hline \multirow{6}{*}{$\begin{array}{l}\text { Heteromastus filiformis } \\
\text { (deposit feeder) }\end{array}$} & HF1 & $0.00542 \mathrm{NDVI}+0.00185 \mathrm{NDVI}^{2 *}+0.00461$ & 0.07 & 2256.6 \\
\hline & HF2 & $-\left(5.710 \times 10^{-5}\right) d_{50}+\left(2.895 \times 10^{-7}\right) d_{50}^{2 *}+0.00315$ & 0.09 & 2250.9 \\
\hline & HF3 & $-0.01192 M^{* *}+0.012022 M^{2 *}+0.003355^{* * *}$ & 0.08 & 2253.7 \\
\hline & HF4 & $-\left(8.2 \times 10^{-4}\right) z+\left(2.62 \times 10^{-4}\right) z^{2}+0.001667^{* * *}$ & 0.01 & 2276.5 \\
\hline & HF5 & $\begin{array}{l}\text { 0.00464 NDVI + 0.00133 } \mathrm{NDVI}^{2}-\left(5.869 \times 10^{-5}\right) d_{50} \\
\quad+\left(2.997 \times 10^{-7}\right) d_{50}^{2}+0.001064 z-\left(3.98 \times 10^{-4}\right) z^{2 *}+0.006524\end{array}$ & 0.11 & 2245.5 \\
\hline & HF6 & $\begin{array}{c}0.00424 \mathrm{NDVI}+0.00127 \mathrm{NDVI}^{2 *}+\left(6.660 \times 10^{-5}\right) d_{50}-\left(9.352 \times 10^{-8}\right) d_{50}{ }^{2} \\
-0.00894 M+0.0171 M^{2}+0.00150 z^{*}-\left(5.50 \times 10^{-4}\right) z^{2}-0.00304\end{array}$ & 0.12 & 2245.2 \\
\hline \multirow{6}{*}{$\begin{array}{l}\text { Bathyporeia pilosa } \\
\text { (surface deposit } \\
\text { feeder) }\end{array}$} & BP1 & $0.0948 \mathrm{NDVI}^{* * *}+0.0194 \mathrm{NDVI}^{2 * * *}+0.118^{* * *}$ & 0.21 & 2005.4 \\
\hline & BP2 & $-0.00281 d_{50}^{* * *}+\left(7.050 \times 10^{-6}\right) d_{50}^{2 * *}+0.282^{* * *}$ & 0.21 & 2004.4 \\
\hline & BP3 & $-0.121 M^{* * *}+0.959 M^{2 * * *}+0.00378^{* * *}$ & 0.31 & 1967.2 \\
\hline & BP4 & $-0.00725 z^{* *}+0.00381 z^{2 * * *}+0.00684^{* * *}$ & 0.06 & 2053.6 \\
\hline & BP5 & $\begin{array}{l}0.0336 \mathrm{NDVI}+0.00710 \mathrm{NDVI}^{2}-0.116 \mathrm{M}^{* * *}+0.908 \mathrm{M}^{2 * * *} \\
-0.00531 z^{*}+0.00181 z^{2 *}+0.0449^{*}\end{array}$ & 0.42 & 1922.5 \\
\hline & BP6 & $\begin{array}{c}0.0323 \text { NDVI }+0.00692 \mathrm{NDVI}^{2}-\left(2.167 \times 10^{-4}\right) d_{50}+\left(5.288 \times 10^{-7}\right) d_{50}{ }^{2} \\
-0.116 M^{* * *}+0.905 M^{2 * * *}-0.00538 z^{*}+0.00183 z^{2}+0.0648\end{array}$ & 0.42 & 1925.7 \\
\hline \multirow{6}{*}{$\begin{array}{l}\text { Nereis diversicolor } \\
\text { (omnivore) }\end{array}$} & ND1 & $0.00344 \mathrm{NDVI}^{*}+0.00443 \mathrm{NDVI}^{2 * *}+0.00155^{*}$ & 0.11 & 2465.1 \\
\hline & ND2 & $-\left(1.06 \times 10^{-4}\right) d_{50}^{* * *}+\left(4.526 \times 10^{-7}\right) d_{50}^{2 * * *}+0.00636^{* *}$ & 0.18 & 2441.7 \\
\hline & ND3 & $-0.00908 M^{* * *}+0.00910 M^{2 * * *}+0.00242^{* * *}$ & 0.13 & 2460.4 \\
\hline & ND4 & $-0.00300 z^{* * *}+\left(9.03 \times 10^{-4}\right) z^{2 * * *}+0.00281^{* * *}$ & 0.11 & 2465.0 \\
\hline & ND5 & $\begin{array}{l}0.00319 \mathrm{NDVI}^{*}+\left(8.6 \times 10^{-4}\right) \mathrm{NDVI}^{2 *}-\left(1.6 \times 10^{-4}\right) d_{50 *}^{* *} \\
\quad+\left(6.272 \times 10^{-7}\right) d_{50}{ }^{2 * * *}+0.00513 M-0.00807 M^{2 *}+0.0121^{* * *}\end{array}$ & 0.19 & 2438.6 \\
\hline & ND6 & $\begin{array}{l}0.00311 \mathrm{NDVI}^{*}+\left(8.36 \times 10^{-4}\right) \mathrm{NDVI}^{2 *}-\left(1.49 \times 10^{-4}\right) d_{50}{ }^{* * *} \\
\quad+\left(5.994 \times 10^{-7}\right) d_{50}^{2 * * *}+0.00487 \mathrm{M}-0.00768 M^{2 *}-\left(2.57 \times 10^{-4}\right) \mathrm{Z} \\
\quad+\left(9.186 \times 10^{-5}\right) z^{2}+0.0118^{* * *}\end{array}$ & 0.19 & 2442.4 \\
\hline \multirow{6}{*}{$\begin{array}{l}\text { Pygospio elegans } \\
\text { (deposit feeder) }\end{array}$} & PE1 & $0.0614 \mathrm{NDVI}^{* * *}+0.0184 \mathrm{NDVI}^{2 * * *}+0.0523^{* * *}$ & 0.25 & 2106.0 \\
\hline & PE2 & $-0.00118 d_{50}^{* *}+\left(4.066 \times 10^{-6}\right) d_{50}^{2 * * *}+0.0858^{* *}$ & 0.22 & 2116.5 \\
\hline & PE3 & $-0.0307 M^{* *}+0.0491 M^{2 *}+0.00635^{* * *}$ & 0.38 & 2169.1 \\
\hline & PE4 & $-0.0414 z^{* * *}+0.0101 z^{2 * * *}+0.0434^{* * *}$ & 0.06 & 2053.7 \\
\hline & PE5 & $\begin{array}{l}0.0286 \mathrm{NDVI}^{*}+0.00824 \mathrm{NDVI}^{2 *}-0.0321 z^{* * *} \\
+0.00763 z^{2 * *}+0.0590^{* * *}\end{array}$ & 0.41 & 2039.7 \\
\hline & PE6 & $\begin{array}{l}0.0303 \mathrm{NDVI}^{*}+0.00867 \mathrm{NDVI}^{2 *}-\left(9.06 \times 10^{-4}\right) d_{50}{ }^{*} \\
\quad+\left(3.205 \times 10^{-6}\right) d_{50}{ }^{2 *}+0.0293 M^{* *}-0.0468 M^{2 *}-0.03018 z^{* * *} \\
\quad+0.0076180 z^{2 * *}+0.116^{* * *}\end{array}$ & 0.44 & 2031.3 \\
\hline
\end{tabular}



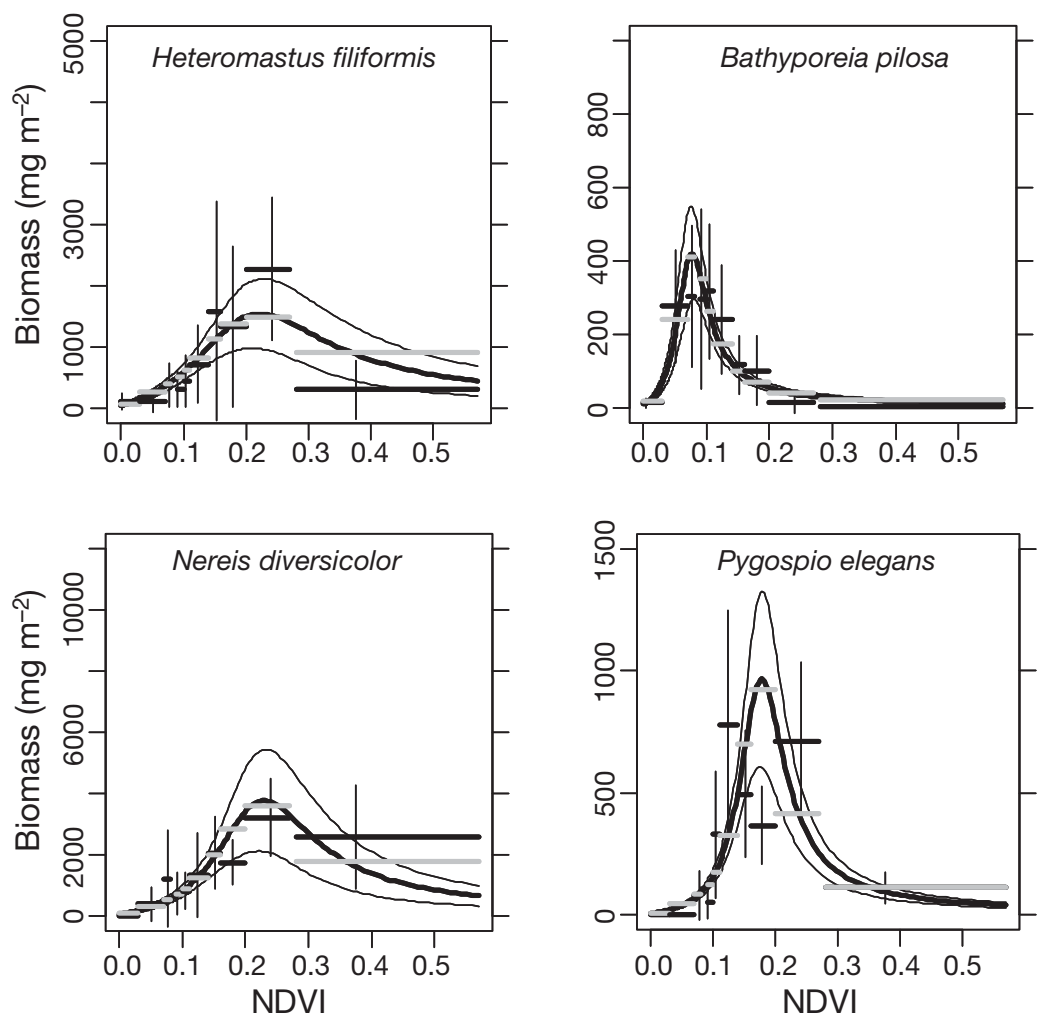

Fig. 5. Response of the biomass of 4 macrobenthos species to vegetation index NDVI. See Fig. 4 for further explanation
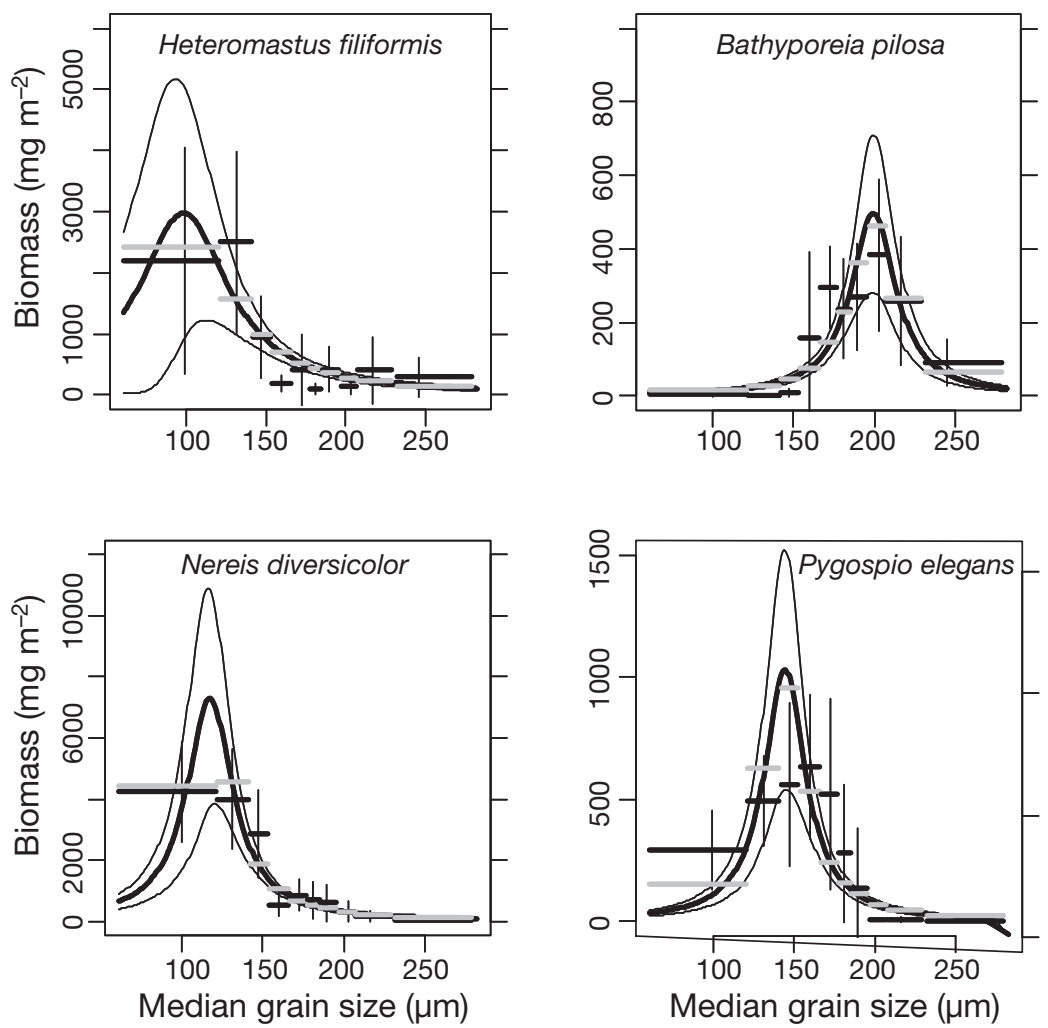

Fig. 6. Response of the biomass of 4 macrobenthos species to the median grain size of the sediment. See Fig. 4 for further explanation 

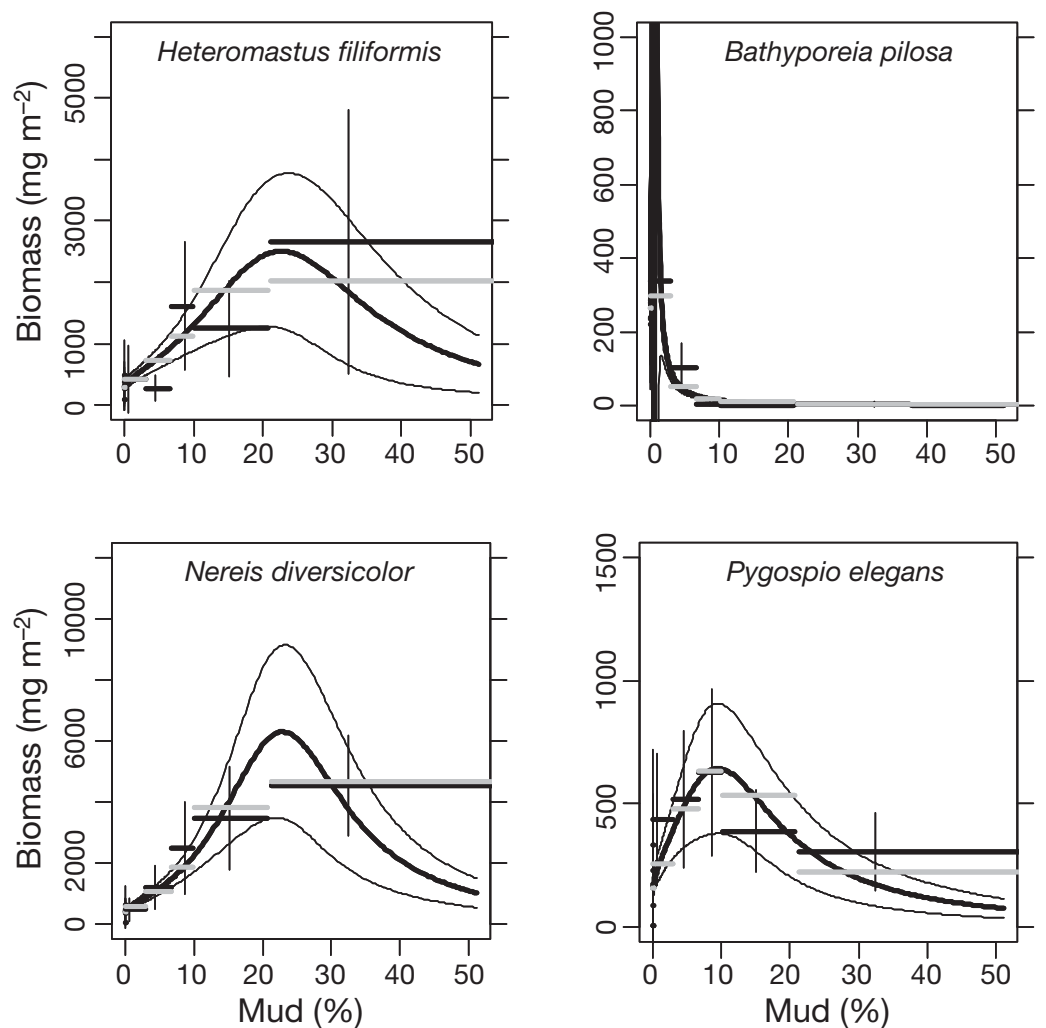

Fig. 7. Response of the biomass of 4 macrobenthos species to the mud percentage of the sediment. See Fig. 4 for further explanation
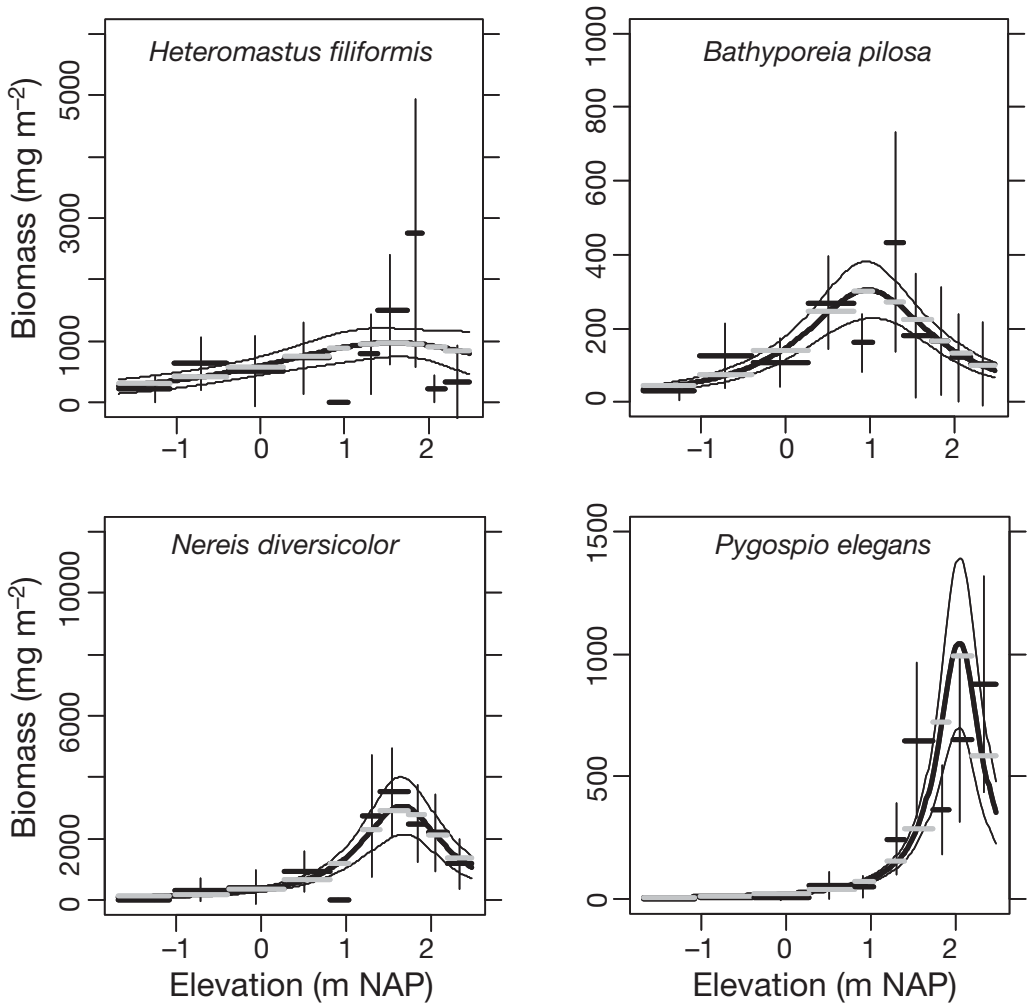

Fig. 8. Response of the biomass of 4 macrobenthos species to elevation. (NAP: Normaal Amsterdams Peil, ca. mean sea level). See Fig. 4 for further explanation 

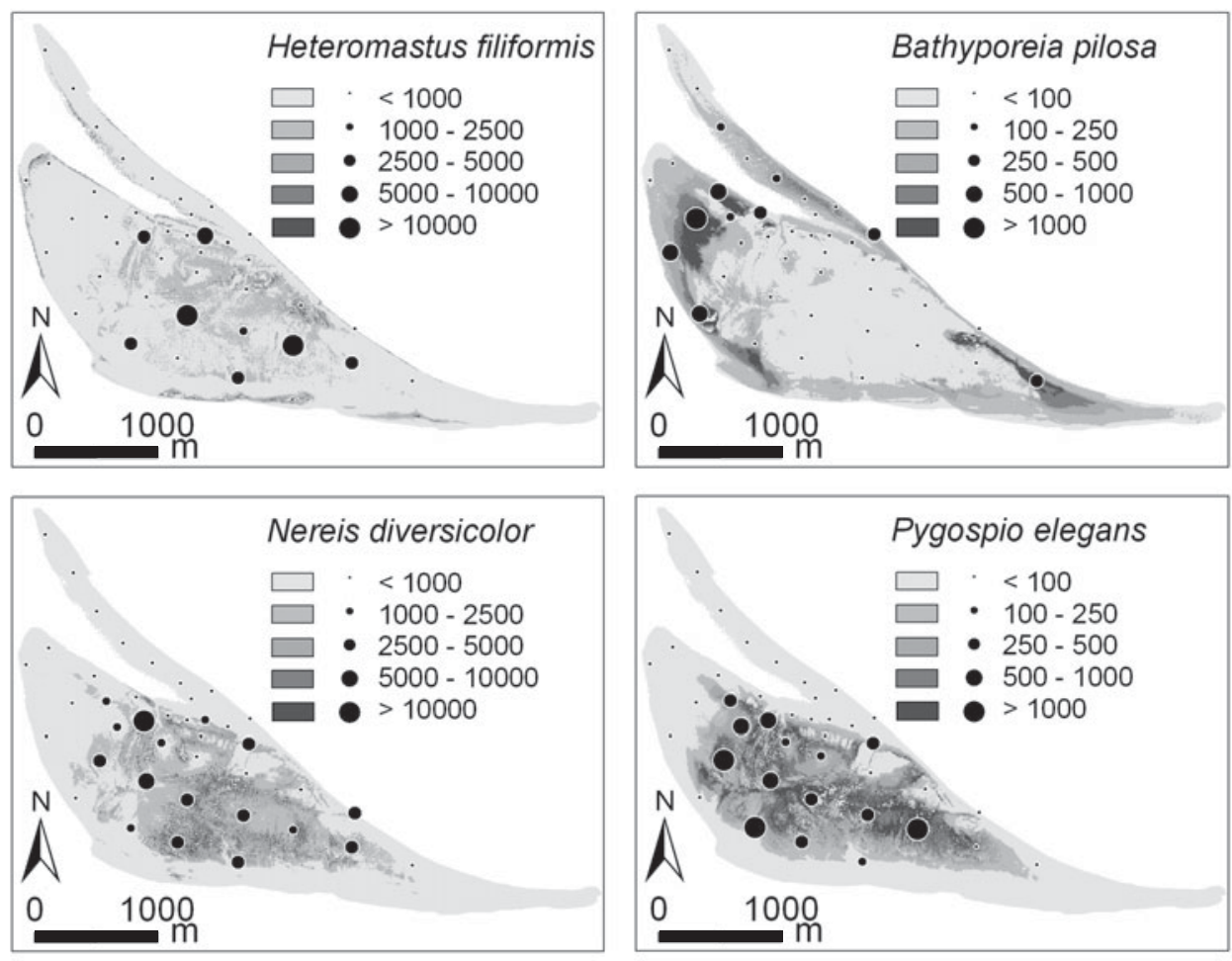

Fig. 9. Prediction of the spatial distribution of biomass $\left(\mathrm{mg} \mathrm{m}^{-2}\right)$ of 4 macrobenthos species based on the maps of the environmental variables derived from the airborne remote sensing images of 2006 . The best response models (see Table 4) are used for the prediction. •: observed biomass from in situ sampling in August 2006

predictions of macrobenthos biomass were based on response models using sediment data predicted from remote sensing, rather than in situ sediment data. In this case, all predictions of macrobenthos biomass were significant, except for $H$. filiformis (Table 5).

\section{DISCUSSION}

A combination of in situ and remotely sensed data was used to explain and predict the spatiotemporal distribution of the macrobenthos on a large intertidal flat, adopting a response model approach. Response models have been applied successfully to macrobenthos in soft sediments (e.g. Ysebaert et al. 2002, Thrush et al. 2003, 2005, Ellis et al. 2006). Response models represent a top-down correlation between the macrobenthos and the environmental variables. This correlation may not, however, always reflect a direct cause and effect relationship. Macrobenthos are ecosystem engineers that can structure their environment (Jones et al. 1994), for instance by (de)stabilising the sediment (e.g. Rhoads \& Young 1970, Reise 2002) or by inhibiting the establishment of saltmarsh plants (Van Wesenbeeck et al. 2007). One of the main food sources for macrobenthos, microphytobenthos, can form a protective algal layer on the sediment surface, reducing the resuspension of mud from the sediment by tidal currents (e.g. Paterson \& Black 1999) and promoting mud accumulation, which may subsequently affect macrobenthos composition. Microphytobenthos biomass was also found to correlate with elevation, which controls the photoperiod of microphytobenthos in turbid environments such as the Westerschelde. Thus, many environmental variables covary, and may not necessarily be causative variables.

Previous response models have demonstrated the response of macrobenthos to sediment grain size (e.g. Ysebaert et al. 2002, Thrush et al. 2003), but so far, food availability has not been used in response models (Hewitt et al. 2004). Previous studies in the Westerschelde estuary show that grazers and (surface) deposit feeders mainly feed on microphytobenthos, whereas suspension feeders mainly feed on phytoplankton (Herman et al. 2000). Some species, such as Macoma balthica, may feed on both sources, depending on for instance life stage or food availability (Taghon et al. 1980, Herman et al. 2000, Riisgård \& Kamermans 2001, Rossi et al. 2004). Microphytobenthos can, when resuspended, also provide food for suspension feeders (Decottignies et al. 2007), whereas phytoplankton can deposit during calm conditions and becomes incorporated in the microphytobenthos (MacIntyre et al. 1996, Miller et al. 1996, Safi 2003). In our 
Table 5. Evaluation of the prediction of total biomass $\left(\mathrm{mg} \mathrm{m}^{-2}\right)$, species richness, and biomass $\left(\mathrm{mg} \mathrm{m}^{-2}\right)$ of key species, using different models, including the vegetation index NDVI, median grain size $d_{50}$ mud content $M$ and elevation $z$. The subscripts 'air' and 'in situ' refer to data derived from remote sensing and from field sampling, respectively. Observed values are expressed as a function of predicted values at the same station, with coefficient of determination $R^{2}$, SE, probability $\mathrm{p}$, and number of observations n for summer/autumn 2006

\begin{tabular}{|c|c|c|c|c|c|}
\hline & Variables in predictor & $R^{2}$ & SE & $\mathrm{p}$ & $\mathrm{n}$ \\
\hline \multirow[t]{2}{*}{ Total biomass } & $\mathrm{NDVI}_{\mathrm{air}}, d_{50, \text { in situ }}$ & 0.40 & 3626 & $<0.0001$ & 39 \\
\hline & $\mathrm{NDVI}_{\text {air, }}, d_{50, \text { air }}$ & 0.43 & 2530 & $<0.0001$ & 39 \\
\hline \multirow[t]{2}{*}{ Species richness } & $\mathrm{NDVI}_{\text {air, }}, d_{50 \text {, in situ }}$ & 0.59 & 1.5 & $<0.0001$ & 39 \\
\hline & $\mathrm{NDVI}_{\mathrm{air}}, d_{50, \text { air }}$ & 0.49 & 1.3 & $<0.0001$ & 39 \\
\hline \multirow[t]{2}{*}{ Heteromastus filiformis } & $\mathrm{NDVI}_{\text {airr }}, d_{50, \text { in situ }}, M_{\text {in situ }}, Z_{\text {air }}$ & 0.59 & 361 & $<0.0001$ & 38 \\
\hline & $\mathrm{NDVI}_{\mathrm{air}}, d_{50, \text { air }}, M_{\text {air }}, z_{\mathrm{air}}$ & 0.01 & 972 & 0.6780 & 39 \\
\hline \multirow[t]{2}{*}{ Bathyporeia pilosa } & $\mathrm{NDVI}_{\text {air }}, M_{\text {in situ }}, z_{\text {air }}$ & 0.73 & 100 & $<0.0001$ & 38 \\
\hline & $\mathrm{NDVI}_{\text {air }}, M_{\text {air }}, z_{\text {air }}$ & 0.80 & 183 & $<0.0001$ & 39 \\
\hline \multirow[t]{2}{*}{ Nereis diversicolor } & $\mathrm{NDVI}_{\text {air }}, d_{50, \text { in situ }}$ & 0.31 & 910 & $<0.0001$ & 39 \\
\hline & $\mathrm{NDVI}_{\text {air }}, d_{50, \text { air }}$ & 0.26 & 760 & 0.0010 & 39 \\
\hline \multirow[t]{2}{*}{ Pygospio elegans } & $\mathrm{NDVI}_{\text {air, }}, d_{50, \text { in situ }}, M_{\text {in situ }}, Z_{\text {air }}$ & 0.18 & 3626 & 0.0002 & 39 \\
\hline & $\mathrm{NDVI}_{\mathrm{air}}, d_{50, \text { air }}, M_{\mathrm{air}}, z_{\mathrm{air}}$ & 0.18 & 2530 & $<0.0001$ & 39 \\
\hline
\end{tabular}

study, the response of most trophic groups and species was best explained using a combination of environmental variables, including sediment properties and food resources. In addition, a number of models with different environmental variables showed similar performance. For example, the response of species richness to NDVI (model SR1 in Table 2) and median grain size (model SR2 in Table 2) was comparable. Nevertheless, our study confirms that the surface deposit feeders responded in particular to microphytobenthos biomass, whereas deep deposit feeders responded strongest to the median grain size of the sediment. Suspension feeders did not respond well to any of the 4 investigated environmental variables, suggesting that other variables (such as current velocity or phytoplankton primary production) may be more important in explaining their biomass. Information on such variables (e.g. from hydrodynamic modelling and remote sensing of water quality parameters) can be added to improve the response models of suspension feeders.

The response models provide a tool to predict the spatial structuring and dynamics of benthic communities. Total biomass and species richness was highest in muddy locations with intermediate elevation, dominated by a high biomass of microphytobenthos. However, each species revealed a unique response to the environmental variables. Application of the response models to maps of the environmental variables derived from remote sensing demonstrated clear differences in spatial distribution of the main macrobenthos species. This technique is therefore suitable for predictions of benthic biomass over vast areas with great spatial resolution, based on only sparsely sampled in situ data. Robustness of the models and ranking of the models was confirmed by running different subsets of the datasets. Response models that included variables from in situ sediment sampling also gave similar predictions of macrobenthos biomass to response models that included sediment grain size variables derived from remote sensing, stressing the consistency of the method. However, the models are not generic. Correlations between the variables can be site-specific to some extent, and macrobenthos biomass may also have been affected by variables not included in the analysis. Hence, the approach can be applied to other intertidal areas, but the models should be fitted for each geographic area, using in situ macrobenthos data, and information on environmental variables either from in situ samples or derived from remote sensing.

As a pronounced temporal variation in both macrobenthic biomass and richness and associated environmental variables was demonstrated, the best predictions are to be expected when in situ macrobenthos and calibration data and remote sensing images are acquired in the same season and year. The seasonal shift in sediment grain size from coarser sediments in winter and spring to finer sediments in summer and autumn has been previously reported (Herman et al. 2001, Van der Wal \& Herman 2007). This phenomenon has been ascribed to a combination of physical and biological factors, including the modifying activity of microphytobenthos and suspension feeders on erosion and deposition of silt (Widdows et al. 2004).

The response models confirmed the sensitivity of the macrobenthos to changes in the environmental conditions between 2004 and 2006. The observed increase in Heteromastus filiformis, Nereis diversicolor and Pygospio elegans, and the decrease in Bathyporeia pilosa could be explained by sediment fining. Based on the response of the species, the small observed change in median grain size from 179 to $172 \mu \mathrm{m}$ or increase in 
mud content from 4.8 to $7.1 \%$ could have caused these changes in biomass (Figs. 6 \& 7). The observed changes in the biomass of macrobenthos species between 2004 and 2005 would also be expected based on the response models as a function of NDVI (Fig. 5), given an observed increase in NDVI from 0.11 to 0.16 between 2004 and 2005. The developments may point to a succession on the tidal flat, with a change to a hydrodynamically more stable environment, in line with the long-term morphological change of intertidal flats in the Westerschelde. The response models predict that such a development may ultimately lead to a decrease in total biomass of macrobenthos and diversity once a threshold for NDVI, sediment grain size or elevation is surpassed. Vice versa, a further decrease in NDVI on large parts of the intertidal flat dominated by microphytobenthos (as is shown on the remote sensing images between 2005 and 2006, see Fig. 3) may also reduce macrobenthos biomass and diversity in future. Remote sensing thus not only provides an efficient, synoptic way for monitoring ecologically and physically relevant variables, but also allows the prediction of the spatiotemporal distribution of benthic macrofauna.

Acknowledgements. This study is based on a project to monitor the ecological effects of an alternative dredging strategy in the Westerschelde, funded by Flanders Hydraulics Research and Maritime Access Division, and coordinated by Y.M.G.P. and S.J.I. (Flanders Hydraulics Research) and A. Govaerts and F. Roose (Maritime Access Division). Rijkswaterstaat provided the 2004 LIDAR data and VITO-TAP provided the 2004 Hymap data. The 2005 and 2006 LIDAR data were obtained by Eurosense, and the 2006 CASI data were obtained by VITO-TAP, both on behalf of Flanders Hydraulics Research and Maritime Access Division. The macrobenthos samples were collected and counted by the Monitor Taskforce, NIOO, Yerseke, supervised by H. Hummel. We thank A. Wielemaker, G. van Hoey, T. Bouma, B. Koutstaal, J. van Soelen, A. Koutstaal, O. van Hoesel, A. Engelberts, R. Markusse, W. Sistermans and the crew of the RV 'Luctor' from NIOO for their help. Finally, we thank the 3 anonymous reviewers for useful suggestions and recommendations. This is NIOO publication number 4275 .

\section{LITERATURE CITED}

Biesemans J, Sterckx S, Knaeps E, Vreys K and others (2007) Image processing workflows for airborne remote sensing. In: Reusen I, Cools J (eds) Proc 5th EARSeL SIG IS Workshop Imaging Spectroscopy; innovation in environmental research, Bruges April 23-25, 2007. VITO, Bruges. Available at: http://5thearselsigis.vgt.vito.be/CD/fullpapers/ Biesemans_final.pdf

Cahoon LB (1999) The role of benthic microalgae in neritic ecosystems. Oceanogr Mar Biol Annu Rev 37:47-86

Clarke KR, Warwick RM (2001) Change in marine communities: an approach to statistical analysis and interpretation, 2nd edn. PRIMER-E, Plymouth Marine Laboratory, Plymouth
Combe JP, Launeau P, Carrère V, Despan D, Méléder V, Barillé L, Sotin C (2005) Mapping microphytobenthos biomass by non-linear inversion of visible-infrared hyperspectral images. Remote Sens Environ 98:371-387

Cracknell AP (1999) Remote sensing techniques in estuaries and coastal zones: an update. Int J Remote Sens 20: 485-496

Créach V, Schricke MT, Bertru G, Mariotti A (1997) Stable isotope and gut analysis to determine feeding relationships in saltmarsh macroconsumers. Estuar Coast Shelf Sci 44:599-611

> Decottignies P, Beninger PG, Rincé Y, Robins RJ, Riera P (2007) Exploitation of natural food sources by two sympatric, invasive suspension-feeders: Crassostrea gigas and Crepidula fornicata. Mar Ecol Prog Ser 334:179-192

> Deronde B, Kempeneers P, Forster RM (2006) Imaging spectroscopy as a tool to study sediment characteristics on a tidal sandbank in the Westerschelde. Estuar Coast Shelf Sci 69:580-590

> Ellis J, Ysebaert T, Hume T, Norkko A and others (2006) Predicting macrofaunal species distribution in estuarine gradients using logistic regression and classification systems. Mar Ecol Prog Ser 316:69-83

Fauchald K, Jumars PA (1979) The diet of worms: a study of polychaete feeding guilds. Oceanogr Mar Biol Annu Rev 17:193-284

Graf G (1992) Benthic-pelagic coupling: a benthic view. Oceanogr Mar Biol Annu Rev 30:149-160

Gray JS (1974) Animal-sediment relationships. Oceanogr Mar Biol Annu Rev 12:223-261

> Guisan A, Zimmerman NE (2000) Predictive habitat distribution models in ecology. Ecol Model 135:147-186

Heip CHR, Goosen NK, Herman PMJ, Kromkamp J, Middelburg JJ, Soetaert K (1995) Production and consumption of biological particles in temperate tidal estuaries. Oceanogr Mar Biol Annu Rev 33:1-149

Herman PMJ, Middelburg JJ, van de Koppel J, Heip CHR (1999) Ecology of estuarine macrobenthos. Adv Ecol Res 29:195-240

Herman PMJ, Middelburg JJ, Widdows J, Lucas CH, Heip CHR (2000) Stable isotopes as trophic tracers: combining field sampling and manipulative labelling of food resources for macrobenthos. Mar Ecol Prog Ser 204:79-92

- Herman PMJ, Middelburg JJ, Heip CHR (2001) Benthic community structure and sediment processes on an intertidal flat: results from the ECOFLAT project. Cont Shelf Res 21:2055-2071

> Hewitt JE, Thrush SE, Legendre P, Funnell GA, Ellis J, Morrison M (2004) Mapping of marine soft-sediment communities: integrated sampling for ecological interpretation. Ecol Appl 14:1203-1216

> Holland AF, Shaughnessy AT, Hiegel HM (1987) Long-term variation in mesohaline Chesapeake Bay macrobenthos: spatial and temporal patterns. Estuaries 10:227-245

Jones CG, Lawton JH, Shachak M (1994) Organisms as ecosystem engineers. Oikos 69:373-386

Kerr JT, Ostrovsky M (2003) From space to species: ecological applications for remote sensing. Trends Ecol Evol 18: 299-305

Kromkamp JC, Morris EP, Forster RM, Honeywill C, Hagerthey S, Paterson DM (2006) Relationship of intertidal surface sediment chlorophyll concentration to hyperspectral reflectance and chlorophyll fluorescence. Estuaries Coasts 29:183-196

Levinton JS, Bianchi TS (1981) Nutrition and food limitation of deposit-feeders. I. The role of microbes in the growth of mud snails (Hydrobidae). J Mar Res 39:531-545 
Lopez GR, Levinton JS (1987) Ecology of deposit-feeding animals in marine sediments. Q Rev Biol 62:235-260

MacIntyre HL, Geider RJ, Miller DC (1996) Microphytobenthos: the ecological role of the 'secret garden' of unvegetated shallow water marine habitats. I. Distribution, abundance and primary production. Estuaries 19: 186-201

Meire P, Ysebaert T, van Damme S, van den Bergh E, Maris T, Struyf E (2005) The Scheldt estuary: a description of a changing ecosystem. Hydrobiologia 540:1-11

Méléder V, Launeau P, Barillé L, Rince Y (2003) Cartographie des peuplements du microphytobenthos par télédétection spatiale visible-infrarouge dans un écosystème conchylicole. CR Biol 326:377-389

Menge BA, Olson AM (1990) Role of scale and environmental factors in regulating of community structure. Trends Ecol Evol 5:52-57

Miller DC, Geider RJ, MacIntyre HL (1996) Microphytobenthos: the ecological role of the 'secret garden' of unvegetated shallow water marine habitats. II. Role in sediment stability and shallow-water food webs. Estuaries 19: 202-212

Paterson DM, Black KS (1999) Water flow, sediment dynamics and benthic ecology. Adv Ecol Res 29:155-193

Pearson TH (2001) Functional group ecology in soft-sediment marine benthos: the role of bioturbation. Oceanogr Mar Biol 39:233-267

Rainey MP, Tyler AN, Gilvear DJ, Bryant RG, McDonald P (2003) Mapping intertidal estuarine sediment grain size distributions through airborne remote sensing. Remote Sens Environ 86:480-490

Reise K (2002) Sediment mediated species interactions in coastal waters. J Sea Res 48:127-141

Rhoads DC, Young DK (1970) The influence of deposit feeding organisms on sediment stability and community trophic structure. J Mar Res 28:150-178

Riisgård HU, Kamermans P (2001) Switching between deposit and suspension feeding in coastal zoobenthos. In: Reise K (ed) Ecological comparisons of sedimentary shores. Ecol Stud 151. Springer, Berlin, p 73-100

Rossi F, Herman PMJ, Middelburg JJ (2004) Inter- and intraspecific variation of $\delta^{13} \mathrm{C}$ and $\delta^{15} \mathrm{~N}$ in deposit- and suspension-feeding bivalves (Macoma balthica and Cerastoderma edule): evidence of ontogenetic changes in feeding mode of Macoma balthica. Limnol Oceanogr 49:409-414

Safi KA (2003) Microalgal populations of three New Zealand coastal locations: forcing functions and benthic-pelagic links. Mar Ecol Prog Ser 259:67-78

Sakamoto Y, Ishiguro M, Kitagawa G (1986) Akaike Information Criterion statistics. Reidel Publishing Company, Dordrecht

Sanders HL (1958) Benthic studies in Buzzard Bay. I. Animalsediment relationships. Limnol Oceanogr 3:245-258

Saye SE, van der Wal D, Pye K, Blott SJ (2005) Beach-dune morphological relationships and erosion/accretion: an

Editorial responsibility: Hans Heinrich Janssen,

Oldendorf/Luhe, Germany investigation at five sites in England and Wales using LIDAR data. Geomorphology 72:128-155

Snelgrove PVR, Butman CA (1994) Animal-sediment relationships revisited: cause versus effect. Oceanogr Mar Biol Annu Rev 32:111-177

Taghon GL, Nowell ARM, Jumars PA (1980) Induction of suspension feeding in spionid polychaetes by high particulate fluxes. Science 210:562-564

Thrush SF, Hewitt JE, Norkko A, Nicholls PE, Funnell GA, Ellis JI (2003) Habitat change in estuaries: predicting broad-scale responses of intertidal macrofauna to sediment mud content. Mar Ecol Prog Ser 263:101-112

$>$ Thrush SF, Hewitt JE, Herman PMJ, Ysebaert T (2005) Multiscale analysis of species-environment relationships. Mar Ecol Prog Ser 302:13-26

> Tucker CJ (1979) Red and photographic infrared linear combinations for monitoring vegetation. Remote Sens Environ 8:127-150

Underwood GJC, Kromkamp J (1999) Primary production by phytoplankton and microphytobenthos in estuaries. Adv Ecol Res 29:93-153

> Van der Wal D, Herman PMJ (2007) Regression-based synergy of optical, shortwave infrared and microwave remote sensing for monitoring the grain size of intertidal sediments. Remote Sens Environ 111:89-106

Van der Wal D, Herman PMJ, Ysebaert T (2004) Space-borne synthetic aperture radar of intertidal flat surfaces as a basis for predicting benthic macrofauna distribution. EARSeL eProceedings 3:69-80

- Van Wesenbeeck BK, Van de Koppel J, Herman PMJ, Bakker JP, Bouma TJ (2007) Biomechanical warfare in ecology: negative interactions between species by habitat modification. Oikos 116:742-750

Warwick RM, Goss-Custard JD, Kirby R, George CL, Pope ND, Rowden AA (1991) Static and dynamic environmental factors determining the community structure of estuarine macrobenthos in SW Britain: Why is the Severn estuary different? J Appl Ecol 28:329-345

- Widdows J, Blauw A, Heip CHR, Herman PMJ and others (2004) Role of physical and biological processes in sediment dynamics of a tidal flat in Westerschelde Estuary, SW Netherlands. Mar Ecol Prog Ser 274:41-56

> Yates MG, Jones AR, McGrorty S, Goss-Custard JD (1993) The use of satellite imagery to determine the distribution of intertidal surface sediments of the Wash, England. Estuar Coast Shelf Sci 36:333-344

> Ysebaert T, Meire P, Herman PMJ, Verbeek H (2002) Macrobenthic species response surfaces along estuarine gradients: prediction by logistic regression. Mar Ecol Prog Ser 225:79-95

Zajac RN, Whitlatch RB (1982) Responses of estuarine infauna to disturbance. II. Spatial and temporal variation in succession. Mar Ecol Prog Ser 10:15-27

Zar JH (1999) Biostatistical analysis, 4th edn. Prentice Hall, Upper Saddle River, NJ

Submitted: September 28, 2007; Accepted: April 21, 2008

Proofs received from author(s): September 2, 2008 